\title{
The Danian-Selandian boundary at Svejstrup with remarks on the biostratigraphy of the boundary in western Denmark
}

\author{
ERIK THOMSEN AND CLAUS HEILMANN-CLAUSEN
}

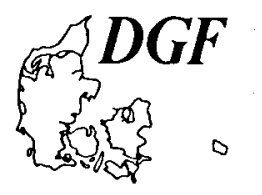
Thomsen, E. \& Heilmann-Clausen, C.: The Danian-Selandian boundary at Svejstrup with remarks on the
biostratigraphy of the boundary in western Denmark. Bull. geol. Soc. Denmark, vol. 33, pp. 341-362, Co-
penhagen, February, 28th, 1985 .

\begin{abstract}
The Danian-Selandian boundary at Svejstrup is characterized by an abrupt facies change from a pure limestone to a terrigeneous marl. The top of the Danian limestone is an intensively burrowed abrasion surface. The Selandian deposits are initiated by a conglomerate of glauconitized and phosphatized limestone pebbles. Although the boundary at Svejstrup is very similar to the nearby section at Hvalløse, the time interval included in the hiatus at Svejstrup is greater than at Hvalløse. The coccoliths and dinoflagellates indicate different ages for the top of the Danian. It is also shown that the Danian sequences in the Harre and the Viborg 1 borings include strata younger than in any previously described Danian sections. At both of these localities a number of coccoliths and a dinoflagellate, Spinidinium densispinatum, hitherto only recorded from the Selandian, occur in the Danian limestone. The top of the Danian at Harre and Viborg 1 is of upper NP4 or lower NP5 age. The calcareous nannofossils of the lower Selandian are completely dominated by reworked Cretaceous forms, whereas reworked dinoflagellates are extremely rare. This difference is probably due to oxidation of the Cretaceous dinoflagellates during reworking. Two new species of dinoflagellates from the Paleocene are described.
\end{abstract}

E. Thomsen and C. Heilmann-Clausen, Department of Palaeoecology, University of Aarhus, DK-8000 Arhus C, September 21, 1983.

In recent years the only outcrop in Denmark revealing the Danian-Selandian boundary has been the limestone quarry at Klintholm, Fyn. In addition to Klintholm, detailed biostratigraphical studies have been carried out only on sections at Lellinge and Hvalløse and on a boring (TUBA 13) in the Copenhagen area (Hansen 1977, Perch-Nielsen \& Hansen 1981).

The locality at Svejstrup (NH 584615), NW of Randers, is located about $17 \mathrm{~km} \mathrm{NW}$ of the previously exposed boundary section at Hvalløse (fig. 1 ). The section was briefly described by $\emptyset$ dum (1926), and Gry (1935) included samples from Svejstrup in his investigation of the Selandian clastic sediments of Denmark. The pit was abandoned about 1950. In this article a brief description of a new excavation is presented and on the basis of calcareous nannofossils and dinoflagellates, the biostratigraphical position of the sequence is compared with the section at Klintholm and with three borings from central Jylland: Harre, Viborg I and a boring at the classical locality of Hvalløse (fig. 1).

The Danian Stage has been variously defined over the years (Hansen 1970, Hardenbol \& Berggren 1978, Thomsen 1981), but there is no general agreement as to the position of the upper boundary of the stage. In this paper we include in the Danian Stage all sediments of typical Danian facies (limestones and marly limestones) that were deposited in continuation of the limestone exposed in the lower boundary type-section at Stevns, and which predate the base of the Selandian marl as defined by Rosenkrantz (1924).

\section{The section at Svejstrup}

As in all previously described sections of the Danian-Selandian boundary, the section at Svejstrup is characterized by an abrupt facies change from nearly pure limestones to marls and clays. The top of the limestone is an abrasion surface, overlain by clastic sediments with a basal conglomerate.

The Danian limestone (units A and B in fig. 1) is a soft, unconsolidated, yellowish white, sandy calcisiltite. It consists mainly of well preserved 


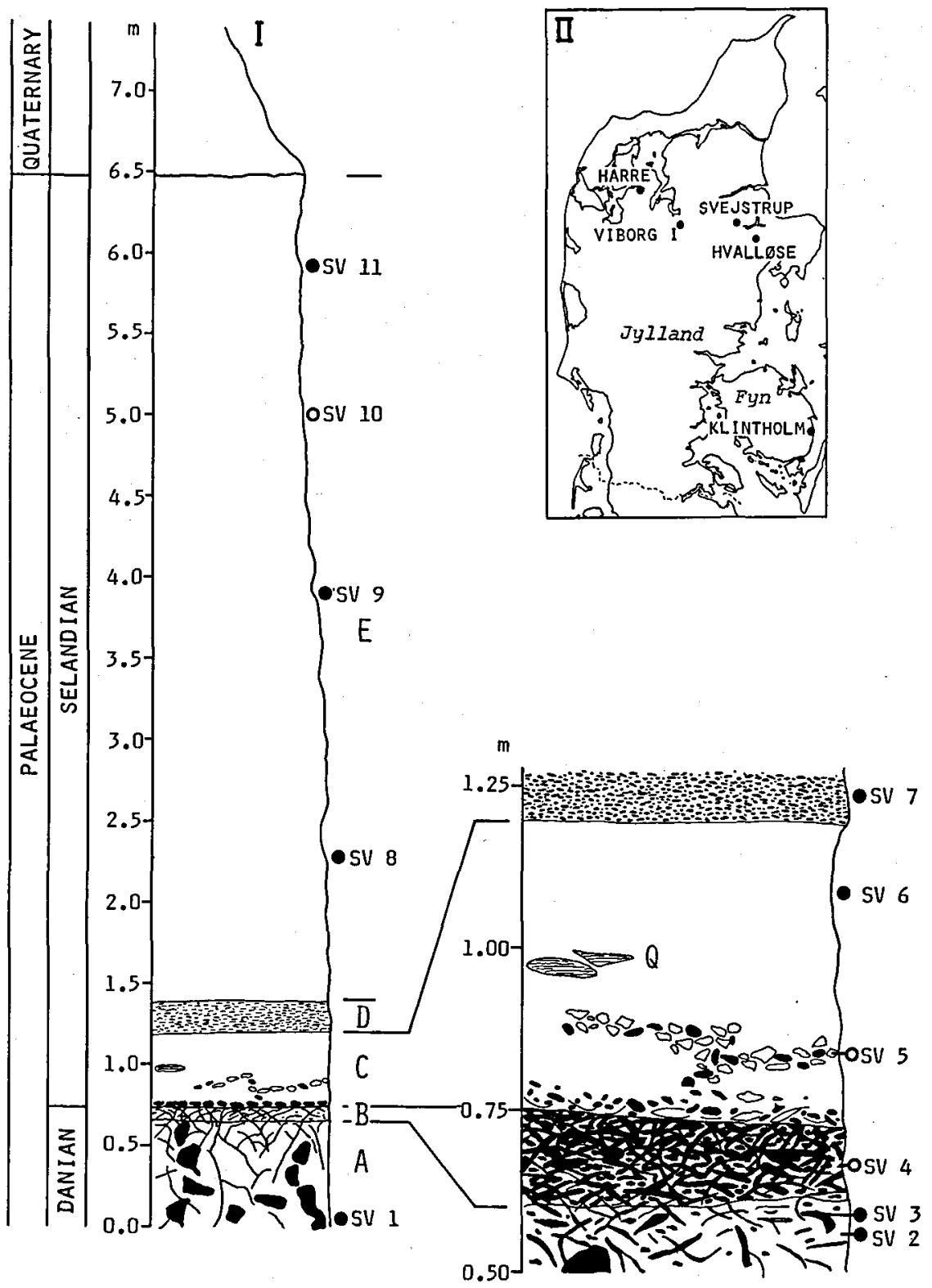

Fig. 1. I. The Danian-Selandian boundary section at Svejstrup. The units A-E are described in the text. Samples shown with a dot are examined for calcareous nannofossils and dinoflagellates. Samples shown with an open circle are examined for calcareous nannofossils only. Q: Quaternary sand. II. Map of Jylland and Fyn showing the position of the investigated localities (Svejstrup: NH 584615).

calcareous nannofossils and foraminifera. Macrofossils are scarce and only irregular echinoids, bryozoans and serpulids are regularly seen. Conspicuous, more or less vertical, rows of nodules of dark flint seem to be related to burrows.

The limestone can be subdivided into two units separated by a $1 \mathrm{~mm}$ thick, slighty undulating, black and white layer of unknown composition. The upper unit (B) which is $10-15 \mathrm{~cm}$ thick is intensively burrowed, and only small remnants of the original limestone are preserved. At the boundary layer between units $A$ and $B$ the density of burrows decreases rapidly, although burrows are still prominent in the upper part of unit 


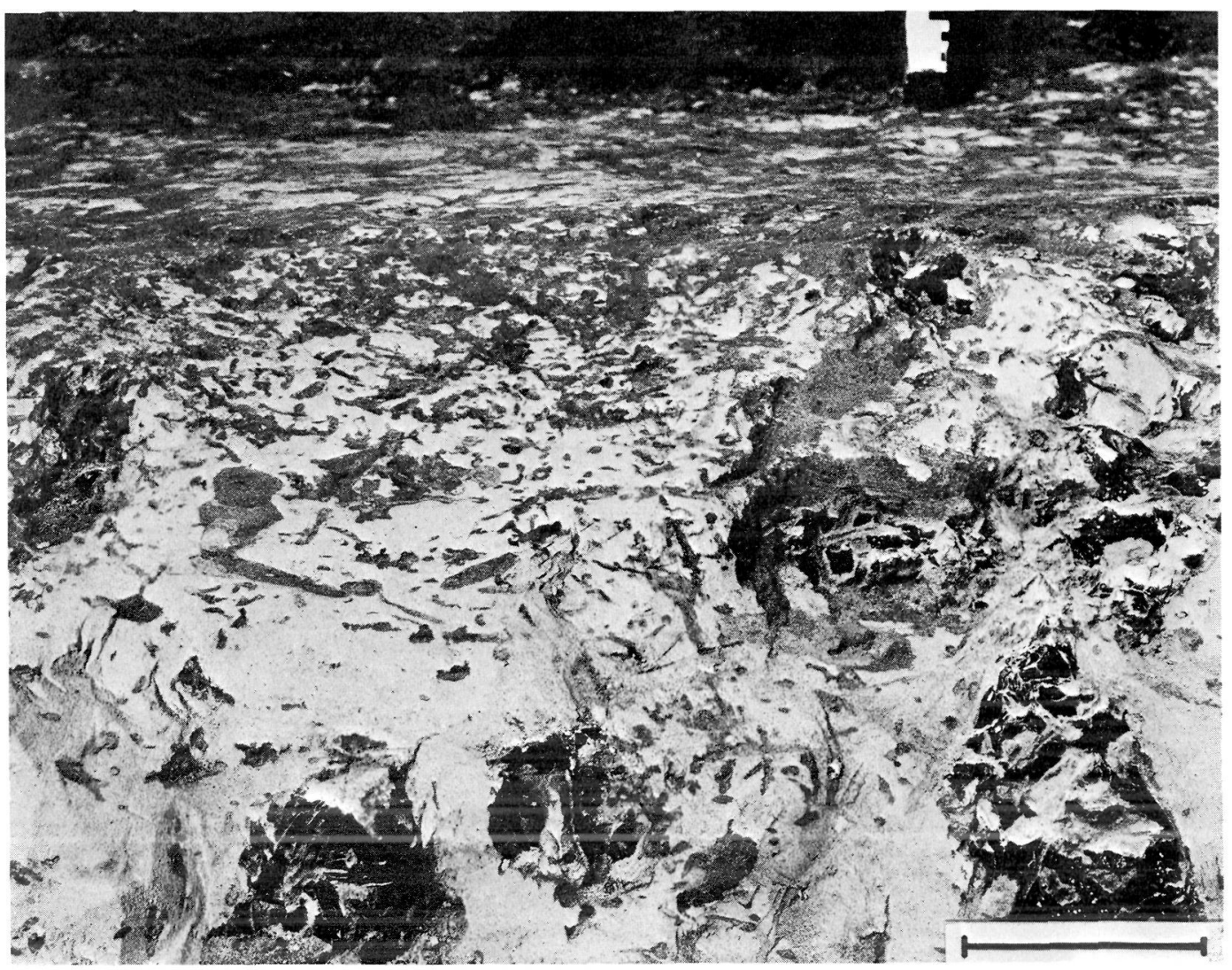

Fig. 2. The top of the Danian limestone at Svejstrup. Vertical section through unit A from the horizontal section shown on fig. 3 to near the bottom of the section (cf. fig. 1). Bar scale $20 \mathrm{~cm}$.

A (fig. 2). Several burrows can be traced to the base of the exposure about $75 \mathrm{~cm}$ below the top of the limestone.

The burrows are filled with a glauconitic marl and several generations of burrows can be distinguished on the basis of their glauconite content. Two types of burrows, both resembling Thallasinoides can be distinguished. Burrows of the most common type, which are between 0.5 and $1.0 \mathrm{~cm}$ in diameter, have random orientation, but in horizontal sections large circular features are occasionally visible (fig. 3). Branching is irregular and there are no clear structures in the fill. Burrows of the second type are between 1,5 and $5 \mathrm{~cm}$ in diameter, most of them in the range of 2 to 3 $\mathrm{cm}$. Their orientation seems to be predominantly horizontal, and internal structures have not been observed.

The base of the Selandian marl is a $7-15 \mathrm{~cm}$ thick conglomerate composed of $0.5-5 \mathrm{~cm}$ large, rolled, glauconitized and phosphatized, limestone pebbles. Some of the pebbles can be recognized as moulds of irregular echinoids, gastropods, and corals. A few of the pebbles served as a substrate for oysters. The conglomerate contains, especially in its lowermost part, numerous specimens of the terebratulid brachiopod Carneithyris lens. The brachiopod shells are crushed but otherwise well-preserved. The matrix is a sandy grey, glauconitic marl. The conglomerate grades upwards into a less glauconitic, grey marl (unit C on fig. 1). Unit $\mathrm{C}$ is referred to the Lellinge Greensand.

From 10 to $45 \mathrm{~cm}$ above the base of the conglomerate the marl is highly brecciated and shows no visible primary sedimentary structures. The lower part of unit $\mathrm{C}$ is folded and contains angular fragments of soft Danian limestone and pebbles similar to those in the basal conglomerate. This layer is followed by a horizon with up to 


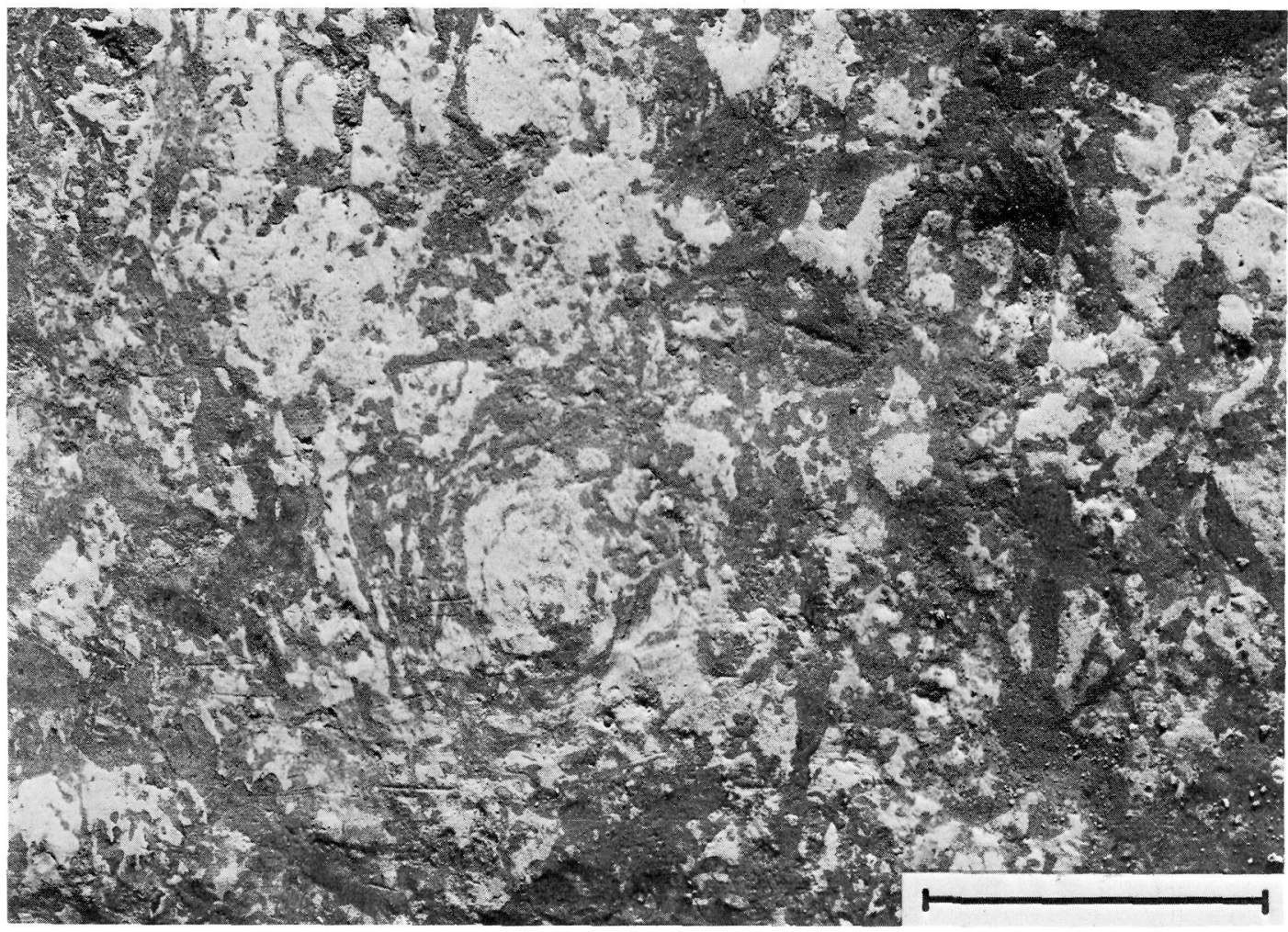

Fig. 3. Horizontal section of the Danian limestone in the uppermost part of unit A a few centimeters below the boundary to unit B (cf. fig. 1). The section shows the distribution and the shape of the burrows. Note the circular arrangement of burrows near the centre of the photograph. Bar scale $20 \mathrm{~cm}$.

$5 \mathrm{~cm}$ thick lenses of well-sorted, yellow, Quaternary sand ( $\mathrm{Q}$ in fig. 1).

The folded "conglomerate" is clearly not in situ. It seems to consist of parts of the basal conglomerate mixed with limestone fragments from the top of the Danian limestone. The presence of lenses of Quaternary sand at the same general level suggests that the conglomerate is a result of glacio-tectonical disturbance.

Above the upper part of unit $\mathrm{C}$ the sequence seems undisturbed. The light grey marl of unit $\mathrm{C}$ is sharply overlain by the dark grey marl of unit D which contains numerous 1-2 mm thick horizontal, or sub-horizontal burrows resembling Chondrites. The burrows are filled with a sediment similar to the marl of unit $\mathrm{E}$ above. Unit $\mathrm{E}$ is a light grey marl with several up to $30 \mathrm{~cm}$ thick, slightly darker layers. Units $\mathrm{D}$ and $\mathrm{E}$ are referred to the Kerteminde Marl. The Palaeocene sequence is overlain by about $3 \mathrm{~m}$ of Quaternary glacial sediments.

\section{Calcareous nannofossil stratigraphy}

The coccolith distribution in the Danian and Selandian of Denmark has been investigated by Perch-Nielsen (1969a, 1969b, 1971b, 1979a, 1979b) and Romein (1979). Perch-Nielsen (1979a) identified ten subzones in the Danian (D1-D10) and two in the Selandian (S1-S2). The subzonal boundaries are based on the first occurrences of species. A simplified version of the Perch-Nielsen (1979a) zonation is adopted here (fig. 4).

The Chiasmolithus danicus Subzone is modified to include the interval from the first occurrence of $C$. danicus to the first occurrence of Neochiastozygus modestus. The subdivision of this interval into two subzones, D5 and D6, is not used, because of the difficulty of distinguishing the index species of D6 (Prinsius tenuiculum) from the index species of D4 (Prinsius dimorphosus). 


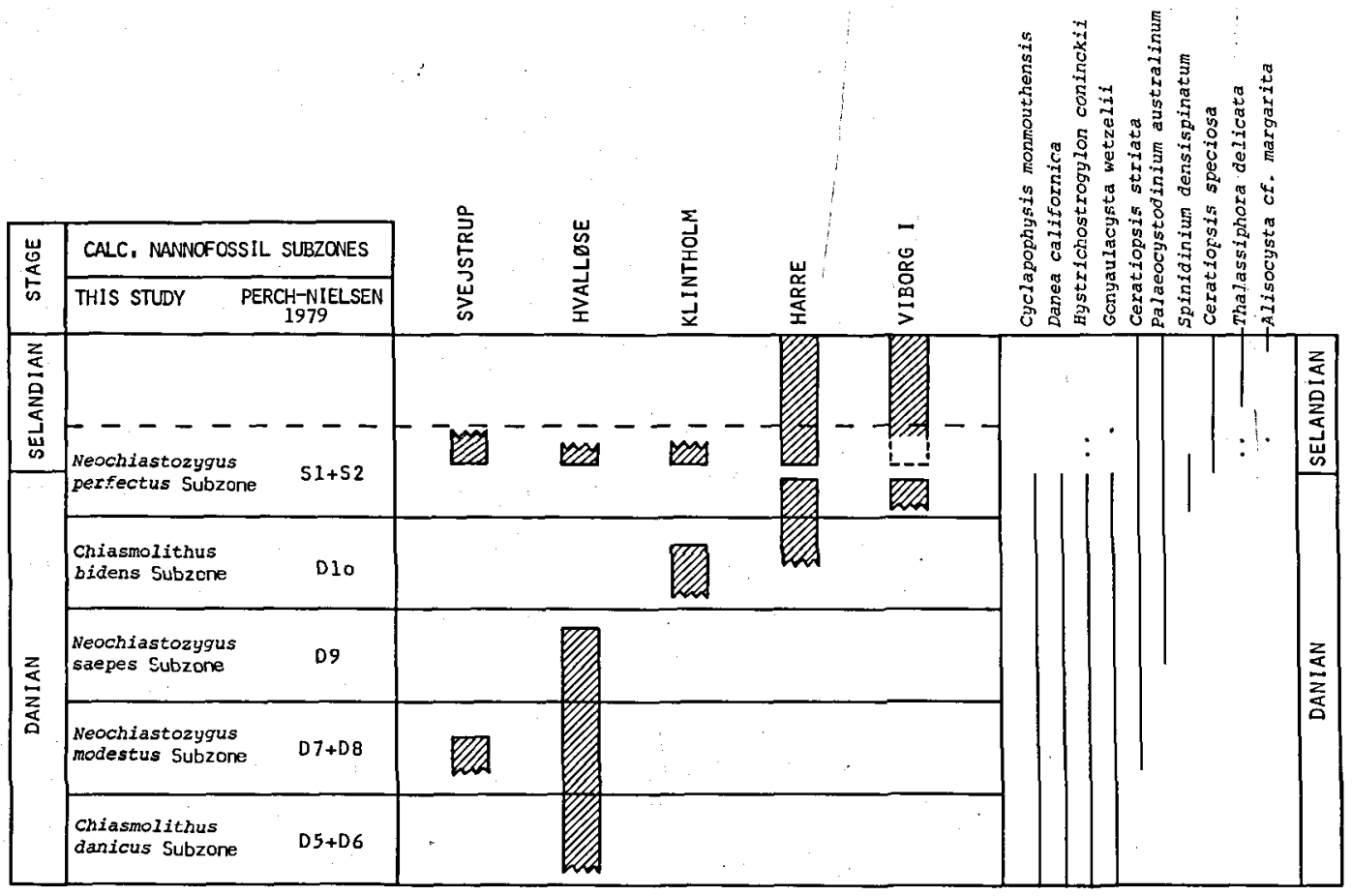

Fig. 4. Correlation of the investigated sections on the basis of calcareous nannofossils and dinoflagellates. Dots indicate rare occurences. The calcareous nannofossil zones used in this study and the equivalent subzones of Perch-Nielsen (1979a) are shown on the left.

The Neochiastozygus modestus Subzone is modified to include the interval from the first occurrence of $N$. modestus to the first occurrence of Neochiastozygus saepes. This interval was subdivided into subzones D7 and D8, but the Prinsius martinii Subzone (D8) was difficult ot recognize. $P$. martinii evolves gradually from $P$. dimorphosus. Both species are small, and in light microscopy it is very difficult to define the first appearance of typical $P$. martinii. Furthermore, SEM examination of material from several borings in the Danish area (e.g. the Hvalløse boring) shows that $P$. martinii and Neochiastozygus saepes, index species of subzone D9, appear at approximately the same level.

Perch-Nielsen (1979a) subdivided the Lower Selandian into two subzones: the Neochiastozygus perfectus Subzone (S1) and the Toweius selandianus Subzone (S2). This subdivision is not maintained since both species are present from the base of the Selandian in all the investigated sections. Toweius selandianus, together with larger forms of the same genus, is very common in many samples. They are all considered to fall within the morphological range of Toweius pertusus (Sullivan) Romein (plate 1). The upper boundary of the Neochiastozygus perfectus Subzone is not defined.

Only the dominant and the stratigraphically important species were registered.

The three samples of Danian limestone from Svejstrup which were investigated (fig. 5) contain a rich and mostly well preserved nannofossil flora. All samples can be assigned to the Neochiastozygus modestus Subzone because of the presence of the index fossil, while Neochiastozygus saepes is absent (fig. 4). Other important species are listed in figure 5. Reworked Cretaceous coccoliths are absent.

The nannofossil flora of the Selandian marl is generally well preserved, especially in the lower part. However, from the base to the top of the sequence the proportion of reworked Cretaceous nannofossils increases rapidly from less than $1 \%$ to more than $99,5 \%$.

Samples SV3 (from a Selandian burrow in the Danian limestone), SV6, and SV7 contain sev- 


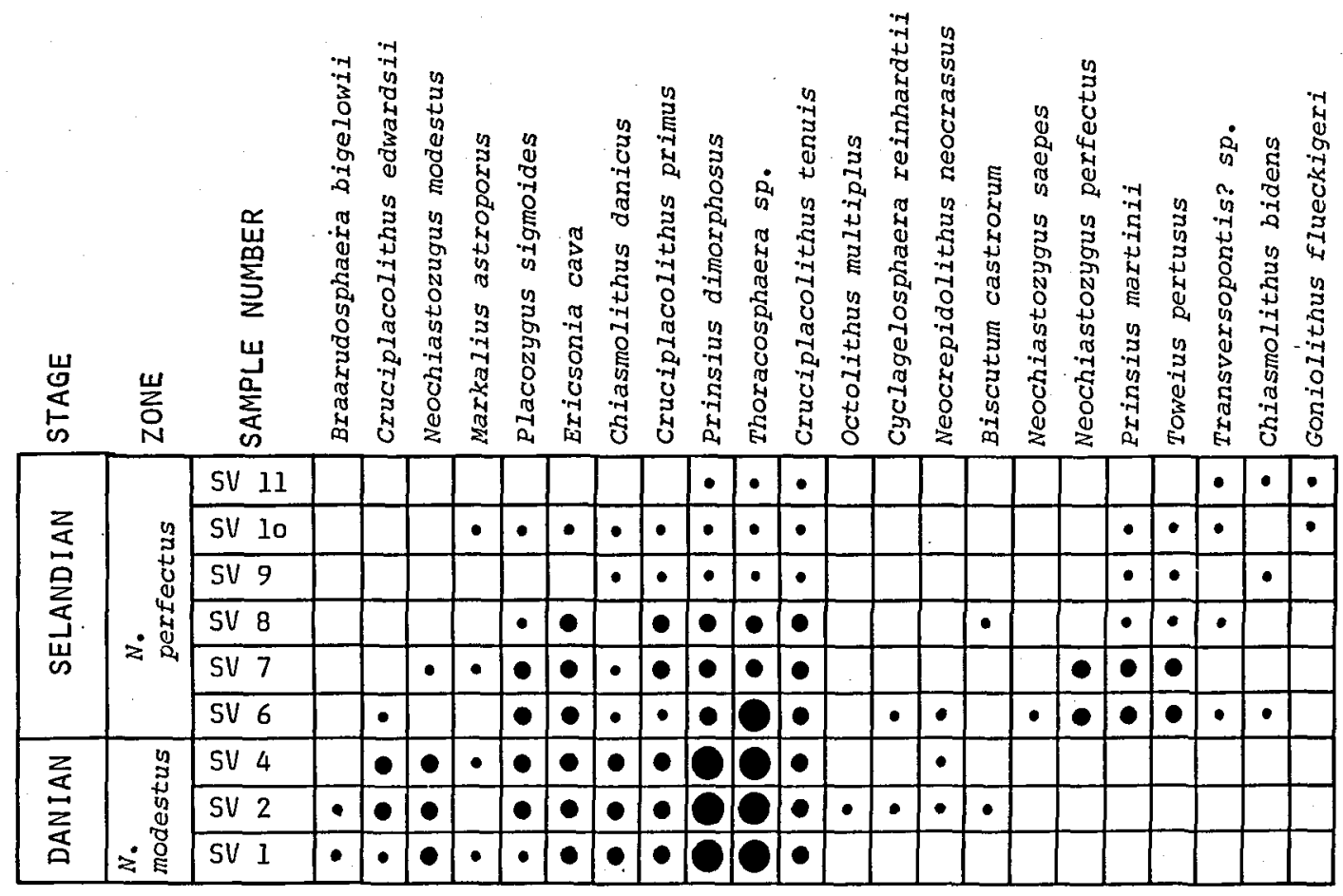

Fig. 5. Distribution of calcareous nannofossils and zonal assignment for the Danian-Selandian boundary section at Svejstrup.

eral stratigraphically important species: Neochiastozygus perfectus, Toweius pertusus, Chiasmolithus bidens and large forms of Prinsius martinii. The samples SV8-SV11 are poor in nonCretaceous coccoliths, and of the species mentioned above only $C$. bidens has been found. The Selandian marl sequence can be assigned to the Neochiastozygus perfectus Subzone.

It should be noted that the limestone pebbles in the basal conglomerate of the Selandian contain a nannofossil flora similar to that of the underlying limestone.

A boring $50 \mathrm{~m} \mathrm{~W}$ of the classic boundary locality at Hvalløse has produced a continuous core across the boundary, from the lowermost Selandian marl.to $71.5 \mathrm{~m}$ into the Danian limestone.

The samples from the lowermost $31 \mathrm{~m}$ contain Chiasmolithus danicus while Neochiastozygus modestus is absent (fig. 4). The interval can therefore be assigned to the Chiasmolithus danicus Subzone. $N$. modestus has its first appearance $38.5 \mathrm{~m}$ below the boundary while the earliest Neochiastozygus saepes occur $9 \mathrm{~m}$ below the boundary. Since Chiasmolithus bidens is absent, the top of the Danian at Hvalløse can be assigned to the Neochiastozygus saepes Subzone.

The Selandian marl contains a flora that is very similar to that in the lowermost Selandian at Svejstrup, and it can be placed in the Neochiastozygus perfectus Subzone.

At Klintholm the sequence comprises $2 \mathrm{~m}$ of $\mathrm{Da}$ nian bryozoan limestone overlain by about $1 \mathrm{~m}$ of Selandian marl. Samples from the limestone contain Chiasmolithus bidens and large forms of Prinsius martinii, while Neochiastozygus perfectus is absent. The samples are therefore assigned to the Chiasmolithus bidens Subzone (fig. 4). The marl contains the index species of the Neochiastozygus perfectus Subzone.

The Harre boring produced a continous core across the Selandian-Danian boundary $1.1 \mathrm{~m}$ into the Danian limestone. The basal Selandian is an olive grey marl while the upper part of the $\mathrm{Da}$ nian is a light grey, sandy calcisiltite with flintbands. The top of the Danian limestone is marked by an unconformity and is intensively bioturbated. Three additional samples were from 
$1.6 \mathrm{~m}$ below the boundary, and from a bryozoan limestone $12.6-13.1 \mathrm{~m}$ and $13.6-14.0 \mathrm{~m}$ below the boundary.

The bryozoan limestone samples contain a rich, moderately well preserved flora with Chiasmolithus bidens and large forms of Prinsius martinii (pl. 1). Neochiastozygus perfectus and Toweius pertusus are absent and the samples therefore belong to the Chiasmolithus bidens Subzone. Samples from the sandy calcisiltite $0.4 \mathrm{~m}, 1.1 \mathrm{~m}$, and $1.6 \mathrm{~m}$ below the boundary contain few, but well preserved, coccoliths. The species include Chiasmolithus bidens, Neochiastozygus perfectus and Toweius pertusus (pls. 1,2), and the samples can be assigned to the Neochiastozygus perfectus Subzone (fig. 4).

The lowermost $1 \mathrm{~m}$ of the Selandian contains numerous, well preserved nannofossils. Upwards the preservation is poorer and the proportion of reworked Cretaceous coccoliths increases. Samples $0.1 \mathrm{~m}$ and $0.4 \mathrm{~m}$ above the boundary include Neochiastozygus perfectus, Toweius pertusus and Chiasmolithus bidens. The basal Selandian can therefore be assigned to the Neochiastozygus perfectus Subzone.

Two samples were available from the Danian of the Viborg I core. Bacause of poor recovery the exact positions of the samples relative to the boundary are uncertain, but both are definitively from the Danian, probably from the uppermost two meters of the Danian limestone (Flagler 1940, Dinesen, Michelsen \& Lieberkind 1977). The samples consist of a hard, light olive grey, sandy calcisiltite, rather similar to the uppermost Danian at Harre. There was no recovery from the lowermost $20 \mathrm{~m}$ of the Selandian.

Calcareous nannofossils are exteremely rare and poorly preserved in the Danian limestone. The presence of Neochiastozygus perfectus and Chiasmolithus bidens indicates that the top of the Danian in Viborg $I$ is of the same age as the top Danian of the Harre boring and should be referred to the Neochiastozygus perfectus Subzone (fig. 4).

\section{Dinoflagellate cyst stratigraphy}

The dinoflagellate cysts in the Danian limestone of southern Scandinavia are well known from the works of Morgenroth (1968), De Coninck (1975), Hansen (1977, 1979a, 1979b, 1980), and Kjellström \& Hansen (1981). Dinoflagellates from the Selandian marl of Sweden have been described by De Coninck (1975) and from Denmark by Hansen $(1977,1980)$. The present study is only concerned with species that are stratigraphically important with respect to the Danian-Selandian boundary.

\section{Danian}

The two samples from the Danian at Svejstrup are quite similar with respect to dinoflagellate content (figs 6, 7 and pls. 4-7). Although the index species itself was not found, the Danian at Svejstrup can confidently be correlated with the lower part of the Hafniasphaera cryptovesiculata Subzone of Hansen (1977). Hafniasphaera graciosa, which is present at Svejstrup, has previously been reported only from the $H$. cryptovesiculata Subzone and younger sediments (Hansen 1977, 1980). The occurence of Hystrichokolpoma bulbosum and Spiniferites cornutus and the absence of Palaeocystodinium, exclude an age younger than the early part of the zone.

The presence of typical Ceratiopsis striata (pl. 5 , fig. 3) in sample SV2 is stratigraphically significant. This occurence is the earliest representation of the species in Denmark.

In his study of the dinoflagellates from the Danian of Denmark Hansen (1977) found the genus Palaeocystodinium only at Klintholm and Hvalløse. He concluded that the two localities were younger than any other locality investigated. They were both referred to the upper part of the $H$. cryptovesiculata Subzone.

In the present study Palaeocystodinium australinum (pl. 3, figs 4-6) is found in the uppermost Danian at Klintholm and Hvalløse, thus indicating a younger age than at Svejstrup (fig. 4).

Ceratiopsis striata appears at Hvalløse in a sample $10.4 \mathrm{~m}$ below the top of the Danian (pl. 5, figs 1,2$)$. This sample belongs to the same calcareous nannoplankton subzone (the Neochiastozygus modestus Subzone) as the Danian at Svejstrup.

The uppermost Danian limestone in the Viborg I 


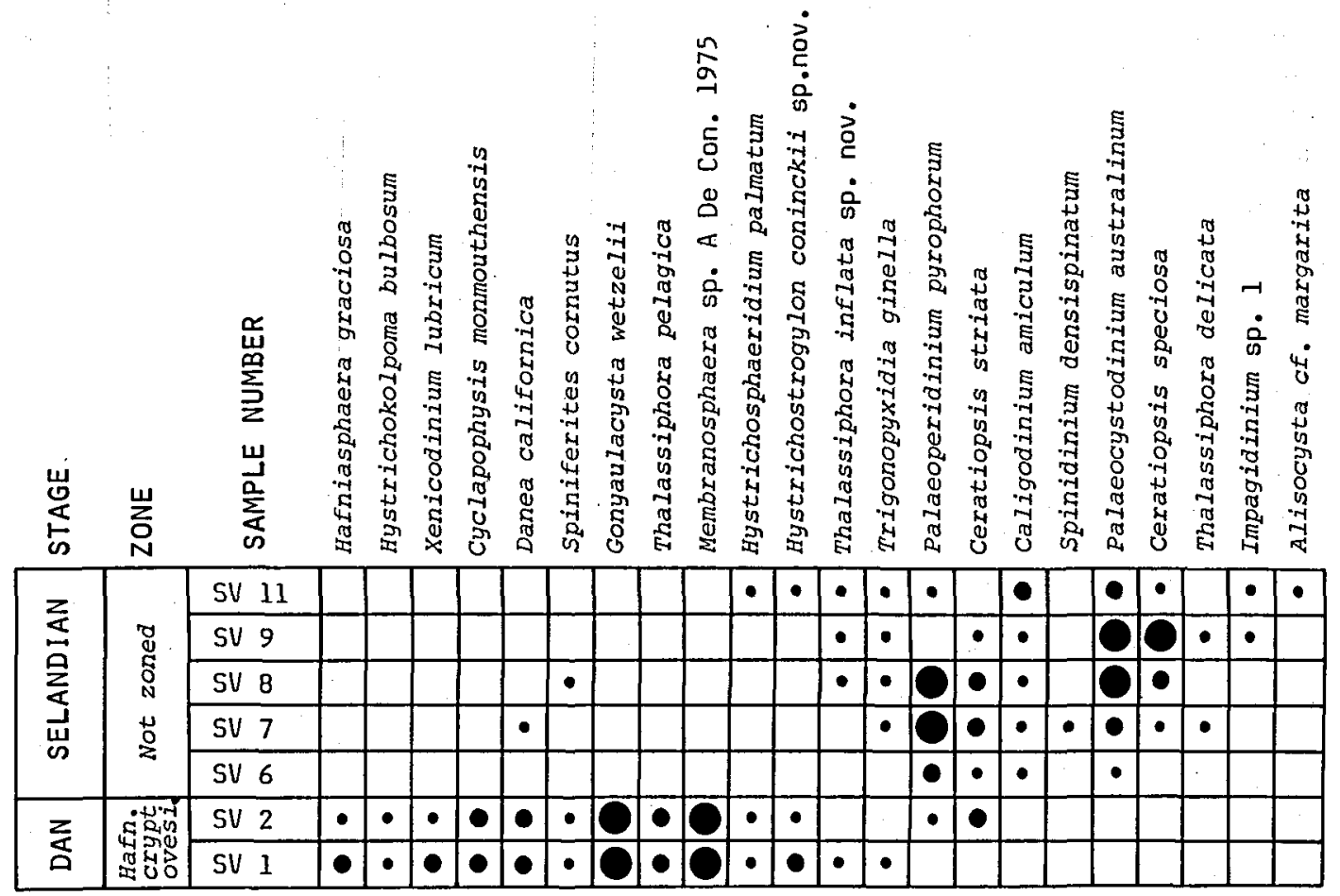

Fig. 6. Distribution of stratigraphically important dinoflagellates and zonal assignment for the Danian-Selandian boundary section at Svejstrup.

and Harre borings contains not only Ceratiopsis striata and Palaeocystodinium australinum but also Spinidinium densispinatum (fig. 4). S. densispinatum has not previously been found in the Danian limestone. It is present in the Selandian, where it has been recorded in the basal part at several localities by Hansen (1980). Similar specimens were illustrated by De Coninck (1975) in his study of the basal Selandian at Klagshamm (Sweden).

The samples from the Viborg I and the Harre borings show that the range of $S$. densispinatum spans the Danian-Selandian boundary, and that the Danian limestone in these two borings is younger than the Danian at other previously described localities.

The Danian limestone in Viborg I represents the last common occurrence in Denmark of a number of characterstic dinoflagellates, e.g. $D a$ nea californica (previously D. mutabilis), Gonyaulacysta wetzelii, Cyclapophysis monmouthensis and Hystrichostrogylon coninckii sp. nov. (pl. 7, figs 9-12).

\section{Selandian}

The stratigraphic distribution of selected species in the Selandian at Svejstrup is shown in fig. 6. A marked floristic change coincides with the Danian-Selandian hiatus. However, most of the species appearing in the Selandian at Svejstrup are already present in the topmost Danian strata at Viborg I and Harre (fig. 4). Only Ceratiopsis speciosa, Thalassiphora delicata and Alisocysta cf. margarita have not been observed in the Danian of these two borings. Their ranges therefore seem to be exclusively post-Danian. At Svejstrup $T$. delicata is very rare and only one specimen of A. cf. margarita was found. Both species are common in the higher parts of the Selandian, above the Kerteminde Marl (fig. 4).

The last occurrence of Ceratiopsis striata, $\mathrm{Pa}$ laeocystodinium australinum and Palaeoperidinium pyrophorum has been used in the North Sea as an indicator of the top of the Danian (Ioakim 1979, Knox, Morton \& Harland 1981). However, all three species are frequent at several lev- 
els in the Selandian at Svejstrup (fig. 7), Viborg I and Harre. In the Viborg I boring their last occurrence is in the upper Selandian, $52 \mathrm{~m}$ above the Danian-Selandian boundary and near the boundary between the so-called "grey, slighty calcareous, clay" and the Holmehus Clay (defined by Dinesen, Michelsen \& Liberkind 1977).

\section{Quantitative distribution}

The relative abundances of dinoflagellates in the section at Svejstrup is shown on fig. 7. The Selandian assemblages fluctuate widely in composition and differ from the Danian assemblages with respect to the dominating species. The abundance of the closely related genera Areoligera and Glaphyrocysta in the basal Selandian, where they may constitute about $70 \%$ of the total planktic assemblage, is particularly noteworthy. In the overlying samples, Palaeoperidinium pyrophorum, Palaeocystodinium australinum and Ceratiopsis speciosa become frequent in that sequence. A similar dominance of Areoligera and

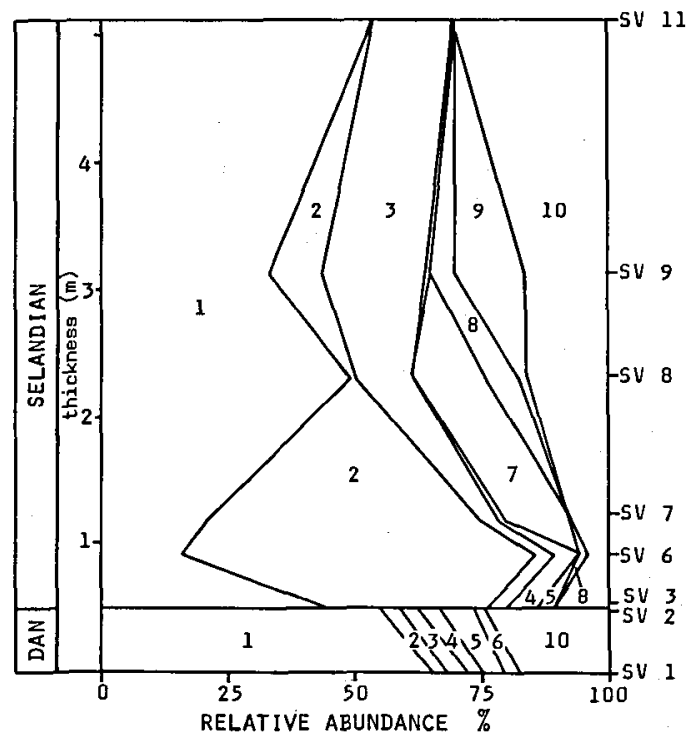

Fig. 7. Relative abundance of organic-walled microplankton across the Danian-Selandian boundary at Svejstrup.

1: Spiniferites + Achomosphaera + Hafniasphaera. 2: Areoligera + Glaphyrocysta. 3: Hystrichosphaeridium + Oligosphaeridium. 4: Cordosphaeridium + Lanternosphaeridium. 5: Membranosphaera sp. A De Con. 1975. 6: Gonyaulacysta wetzelii. 7: Palaeoperidinium pyrophorum. 8: Palaeocystodinium australinum. 9: Ceratiopsis speciosa. 10: Other dinoflagellates + acritarchs.

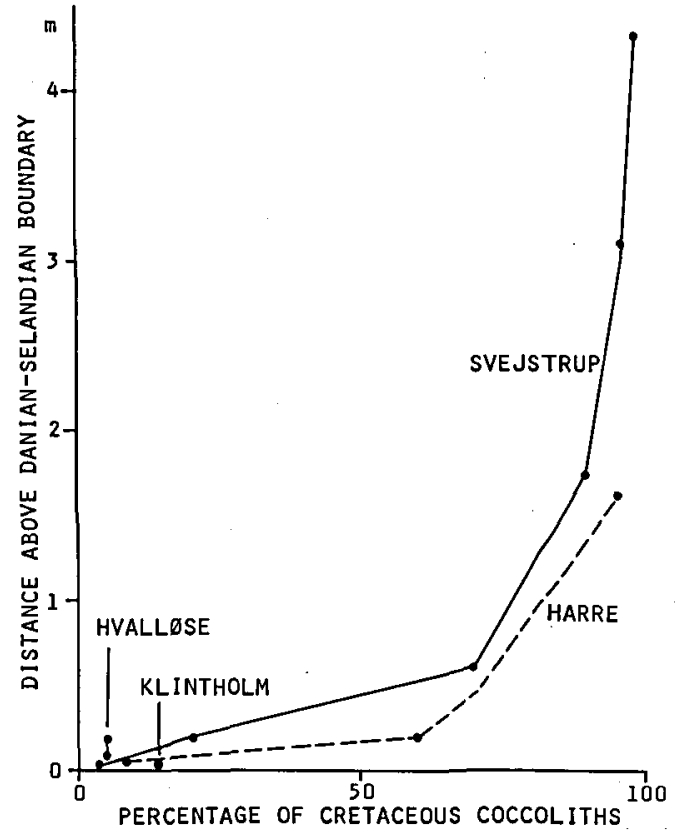

Fig. 8. Estimated percentage of Cretaceous to total calcareous nannofossils in the Selandian at Svejstrup, Harre, Hvalløse, and Klintholm.

Glaphyrocysta in the basal Selandian was observed at Hvalløse and Harre, and has also been described from several Danish localities by Hansen (1980).

The vertical change in the composition of dinoflagellate assemblages in the Selandian at Svejstrup probably reflects increasing water depth during the early phase of the Selandian transgression.

\section{Reworking}

In the lowermost few centimeters of the Selandian marl at Svejstrup and Harre, calcareous nannofossils reworked from the Cretaceous make up only a few percent of the flora. However, their proportion increases rapidly upwards, and about $3 \mathrm{~m}$ above the Danian-Selandian boundary they constitute more than 99 percent of the flora (fig. 8). The Cretaceous coccoliths are extremely well preserved, especially in the lower part. Abundant Nephrolithus frequens indicate that the reworked nannofossils are of Late Maastrichtian age.

In the Danian, calcareous nannofossils from the Cretaceous are rare. None were observed in 
the limestone at Svejstrup, and in the calcisiltite at Harre they constitute only about 1 percent of the flora.

In contrast to the calcareous nannofossils, reworked dinoflagellates seem to be rare in the Selandian. Only a few Chatangiella sp. and one specimen of Odontochitina cf. costata are almost certainly reworked from the Cretaceous.

According to Wilson (1971) the Upper Cretaceous chalk contains about 500 dinoflagellate cysts per gram of sediment. In the Selandian marl an estimate of 8000 cysts per gram seems realistic. A sample from the basal Selandian in Copenhagen contained approximately 10000 cysts per gram (Hansen 1980) while 6000 cysts per gram were found by us in a sample from the upper part of the Selandian in the Viborg I boring.

Calcium carbonate makes up about $60 \%$ of the marl at Svejstrup (Gry 1935). If we assume, as indicated by the calcareous nannofossils, that it is all reworked, then each gram of Selandian marl should contain about $0.6 \mathrm{~g}$ of Cretaceous chalk with about 300 dinoflagellate cysts. Three to four percent of the 8000 dinoflagellates per gram of marl should therefore be reworked. Although such calculations are subject ot a large margin of error it is evident that a measurable proportion of reworked cysts would be expected.

The question now is whether possible reworked Cretaceous dinoflagellates can be distinguished from the Selandian cysts. While the Creataceous element of the calcareous nannoplankton is readily distinguished from the Tertiary element, due to the marked extinction at the Cretaceous-Tertiary boundary, many of the dominant dinoflagellate species in the Selandian were also frequent in the Upper Cretaceous. These include Spiniferites spp., Areoligera spp., Hystrichosphaeridium tubiferum, and Oligosphaeridium complex.

Nevertheless, several distinct species present in the Upper Cretaceous have not been observed in the Selandian marl. In fact, as mentioned above, only a few specimens of two species which became extinct before the beginning of the Selandian have been found. Considering that tens of thousands of Selandian cysts have been examined, this strongly suggests that the dinoflagellates brought into the Selandian sea with reworked Upper Cretaceous chalk were removed during, or before, transportation.
The most likely process capable of removing the dinoflagellates, and not the calcareous nannoplankton, is oxidation. It is well known that organic-walled dinoflagellate cysts may be completely destroyed by oxidation, as seen, for example, in many red marine clays.

The general composition and preservation of the terrestrially derived component of the particulate organic matter in the Selandian marl strongly indicate that it has been oxidized and mechanically degraded. Fragile plant remains, such as fragments of leaf cuticles, are remarkably scarce. Most of the allochthonous organic particles consist of fusinite (charcoal) and unstructured inertinite grains which are highly resistant and may be recycled several times. Furthermore, in polished sections many of the inertinite grains show fine desiccation cracks and reduced reflection in a thin outer zone. Such rims have been ascribed to low temperature oxidation (Chandra 1982).

A problem that should also be considered in relation to reworking concerns the calcareous nannoplankton thought to be of Selandian age. These coccoliths could be reworked from the Danian since the lowermost Selandian and the uppermost Danian at Harre and probably also Viborg I, contain the same species.

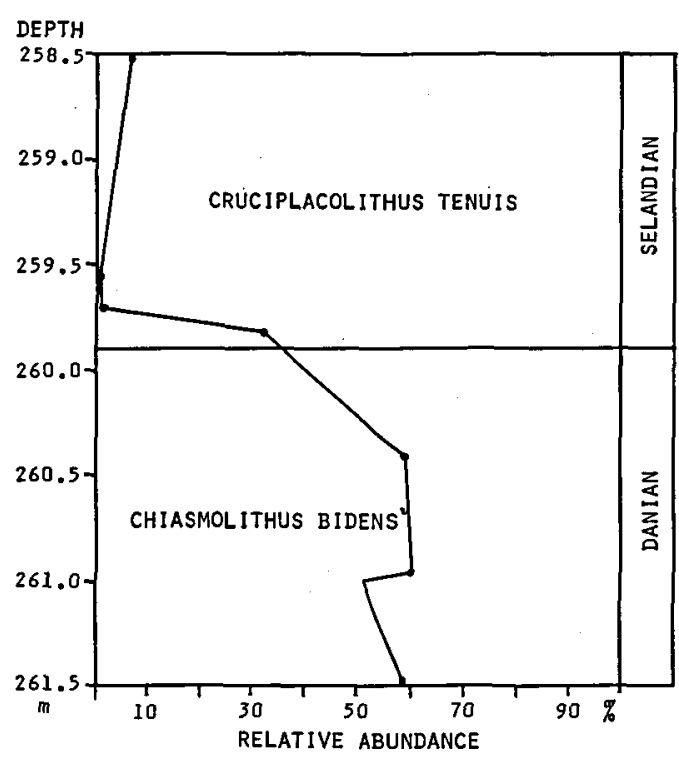

Fig. 9. Relative abundance of Chiasmolithus bidens and Cruciplacolithus tenuis across the Danian-Selandian boundary in the Harre boring. 
However, this is probably not the case. Firstly, the calcisiltite at the top of the Danian in the Harre and the Viborg I borings contains only a few coccoliths while they are very abundant in the lowermost Selandian. Secondly, the various species are present in distinctly different proportions below and above the boundary. This is, for example, shown by the relative abundance of Chiasmolithus bidens and Cruciplacolithus tenuis (fig. 9). In the Danian, C. bidens is more common than $C$. tenuis, while the latter completely dominates in the Selandian. The two species are of approximately the same size, and the different relative abundances cannot be explained by selective transportation. It should be noted, however, that the sample taken $5 \mathrm{~cm}$ above the boundary is intermediate between typical Selandian and Danian samples. This is probably due to mixing in the lowermost Selandian.

\section{Discussion}

As in all previously decribed sections in Denmark, the Danian-Selandian boundary at Svejstrup is an unconformity, marked by an abrupt facies change from limestone to marl.

The biostratigraphical position of the top of Danian and the base of the Selandian at Svejstrup, and at four other boundary sections in western Denmark, has been investigated on the basis of calcareous nannofossils and dinoflagellates. The two groups indicate that the time gap represented by the hiatus varies widely between localities. The age of the earliest Selandian is apparently the same in all sections, so the variation is due to different ages of the top of the Danian.

Independent evidence from the calcareous nannofossils and the dinoflagellates shows that the top of the Danian is oldest at Svejstrup, succeeded by Hvalløse and Klintholm. The youngest Danian is found in the Viborg I and the Harre borings.

In the calcareous nannofossil zonation the $\mathrm{Da}$ nian at Svejstrup belongs to the Neochiastozygus modestus Subzone while at Hvalløse and Klintholm it is referred to the Neochiastozygus saepes and Chiasmolithus bidens Subzones respectively. In the Viborg I and the Harre borings the top of the Danian is assigned to the Neochiastozygus perfectus Subzone.
Within the same upper Danian sequence a number of dinoflagellates appear: Ceratiopsis striata appears in the $N$. modestus calcareous nannofossil Subzone, Palaeocystodinium australinum appears in the $N$. saepes Subzone, and Spinidinium densispinatum appears in the N. perfectus Subzone.

In the calcareous nannofossil zonation the Selandian marl in all localities belongs to the $\mathrm{NeO}$ chiastozygus perfectus Subzone. Therefore, both the top of the Danian and the base of the Selandian belong to the same coccolith subzone in the Harre boring. The same species are found below and above the boundary.

Among dinoflagellates the boundary at Harre and Viborg I marks the last common occurence of a number of characteristic Maastrichtian and Danian species: Danea californica, Gonyaulacysta wetzelii, Cyclapophysis monmounthensis, and Hystrichostrogylon coninckii sp. nov. In the basal Selandian Ceratiopsis speciosa, Thalassiphora delicata, and Alisocysta cf. margarita make their first appearance in the Danish area.

Quantitatively, the lower Selandian is characterized by a rapid succession of dominant species of dinoflagellates. The lowermost $1 \mathrm{~m}$ is dominated by the closely related Areoligera and Glaphyrocysta. Higher in the sequence Palaeoperidinium pyrophorum Palaeocystodinium australinum, and Ceratiopsis speciosa become frequent.

A problem that has received much attention is the age of the top of the Danian in Denmark, which is the type area of this stage (Hansen 1968, 1970, Hardenbol \& Berggren 1978, Perch-Nielsen 1979a, Romein 1979). The correlation of the Upper Danian and the Lower Selandian to the Standard Zonation of Martini (1971) is somewhat problematical; because the index species of NP4 (Ellipsolithus macellus) and of NP5 (Fasciculithus tympaniformis) are missing in the Danish area.

In their absence we have to rely on correlation with sections where both the local Danish index species and the index species of the Standard Zonation are present. Sections that fullfil this requirement are the Nahal Avdat section in Israel and the Caravaca section in Spain (Romein 1979). Borrings from the Deep Sea Drilling Project also provide useful information.

In the Nahal Avdat and Caravaca sections investigated by Romein (1979), Toweius pertusus is the first representative of the genus Toweius. In 

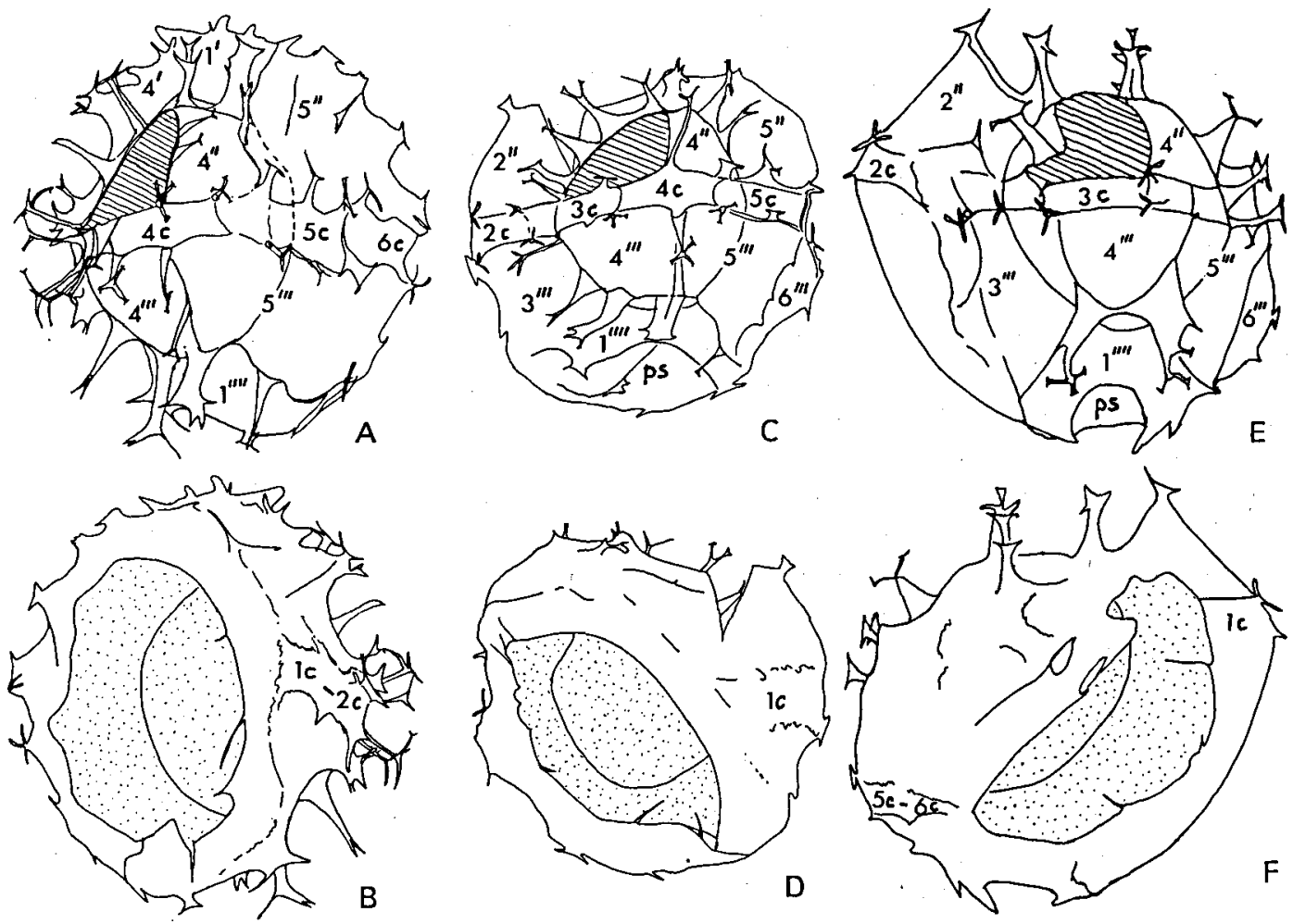

Fig. 10. Hystrichostrogylon coninckii sp. nov, , camera lucida drawings. A: paratype MGUH 16153, dorsolateral view. B: same in ventrolateral view, C, D: holotype, dorsal and ventral view. E, F: paratype MGUH 16154, dorsal and ventral view. Identified paraplates are shown.
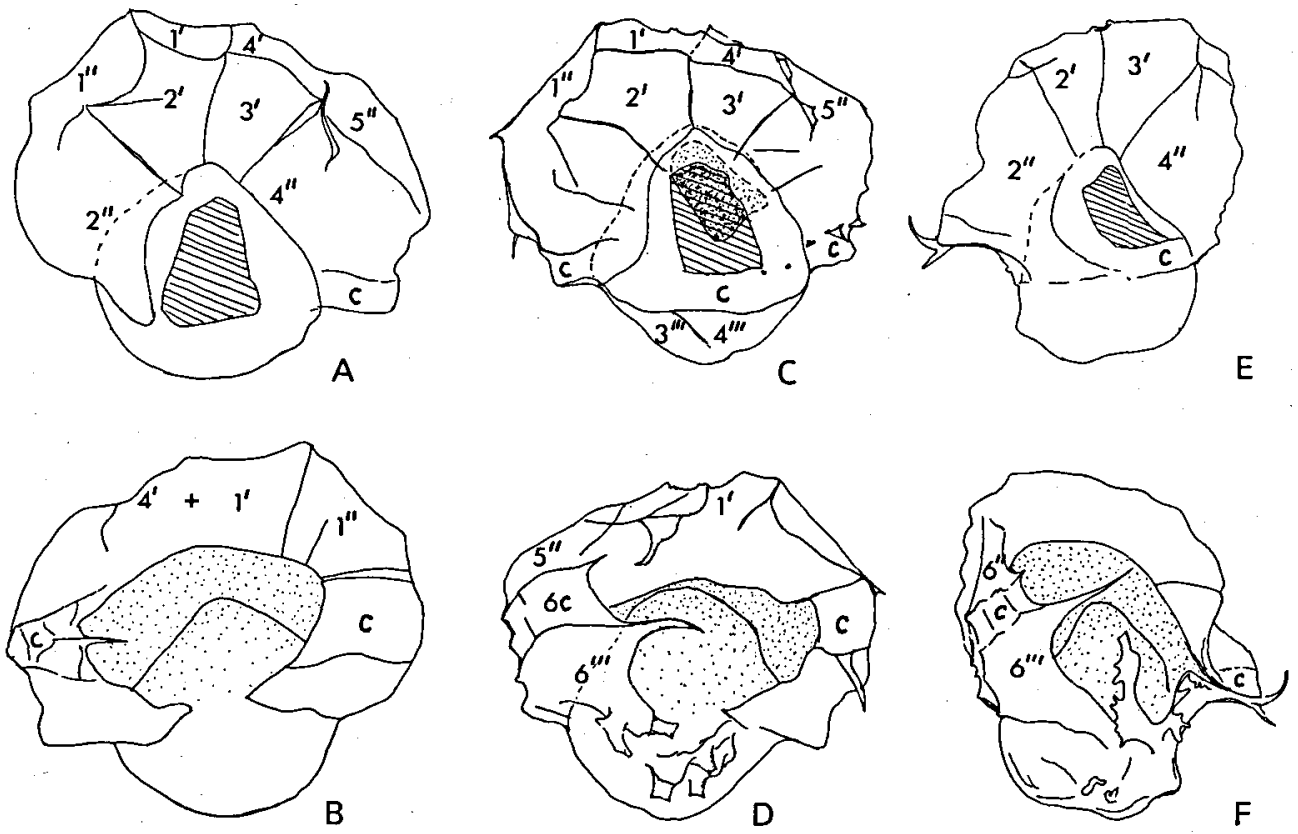

Fig. 11. Thalassiphora inflata sp. nov., camera lucida drawings. A, B: MGUH 16156, dorsal and ventral view. C, D: holotype, dorsal and ventral view. E, F: dorsal and ventral view of specimen from sample SV 1, Svejstrup. Identified paraplates are shown. $c=$ paracingulum. 
both sections it appears approximately at the same time as Fasciculithus tympaniformis which is the index species of NP5.

However, in several DSDP borings, at Site 119 in the Bay of Biscay (Perch-Nielsen 1971a), at Site 356 on the São Paulo Plateau (Perch-Nielsen 1977), at Site 384 near the Grand Banks (Okada $\&$ Thierstein 1979), and at Site 387 on the Western Bermuda Rise (Okada \& Thierstein 1979), species of the genus Toweius occur at deeper levels. They first appear in NP4 and become common in the upper half of the zone. The specimens are in all cases identified as $T$. craticulus, but the illustrations indicate that they fall within th morphological range of Toweius pertusus as accepted in this paper.

The presence of $T$. pertusus suggests that the top of the Danian in the Harre boring cannot be older than the upper part of NP4, and may possibly be of NP5 age. This conclusion is strongly supported by the distribution of Chiasmolithus bidens. In the Nahal Avdat and the Caravaca sections $C$. bidens appears in the upper part of NP4, shortly below $T$. pertusus. In the Harre boring $C$. bidens also appears before $T$. pertusus, occuring in the bryozoan limestone $12.5-14 \mathrm{~m}$ below the boundary.

Neochiastozygus perfectus, may also be useful in correlation with other areas. In the Harre boring it appears in the uppermost $1.6 \mathrm{~m}$ of the Danian. In the DSDP boring, at Site 356 on the São Paulo Plateau, $N$. perfectus occurs in the upper part of NP4 and lower part of NP5. In the Harre boring it is also common in the lowermost Selandian samples.

Perch-Nielsen (1979a) suggested an age corresponding to NP5 for the lowermost Selandian of Denmark on the basis of the same species discussed above.

Acknowledgements. We wish to thank Karen Birgit Pauli for preparing the slides of the calcareous nannofossils and the dinoflagellates, Steen Røj Jacobsen for the photographic work, and Grete Grønlund for typing the manuscript. Ole Bjørslev Nielsen kindly assisted in the field. Dr. R. W. O'B. Knox and Dr. $R$. Harland kindly read the manuscript and suggested many improvements. Dr. R. Wilson kindly corrected the English language of the final version.

\section{Dansk sammendrag}

Som alle hidtil beskrevne grænser mellem danien og selandien er grænsen ved Svejstrup karakteriseret af et brat skifte fra en lys kalk til en grålig mergel. Fra kalkens eroderede overflade udgår talrige Thallasinoides lignende gravegange, som er fyldt med et sediment, der meget ligner selandien mergelen. Mergelens bundlag består af et konglomerat af glauconitiserede og fosfatiserede kalkrullesten indlejret $i$ en sandet glaukonitrig mergel.

Ved hjælp af coccolitter og dinoflagellater er den biostratigrafiske placering af grænselagene ved Svejstrup sammenlignet med tilsvarende lag ved Hvalløse, Klintholm, samt i Viborg I og Harre boringerne. Resultaterne viser, at selandien mergelens basislag overalt har samme biostratigrafiske alder, mens alderen af den underliggende kalk varierer fra lokalitet til lokalitet. Fildst er kalken ved Svejstrup. Derefter følger Hvalløse og Klintholm i nævnte rakkefølge. Yngst er kalken i Viborg I og Harre boringerne. Toppen af danien kalken i Viborg I og Harre kan korreleres med den øverste del af NP4 eller den nederste del af NP5 i standard coccolit-zoneringen af Martini (1971).

\section{Appendix}

Systematic palaeontology

(Claus Heilmann-Clausen)

Class Dinophyceae Fritsch 1929

Order Peridiniales Haeckel 1894.

Family Gonyaulacaceae Lindeman 1928.

Genus Hystrichostrogylon Agelopoulos 1964 emend. Stover \& Evitt 1978.

Hystrichostrogylon coninckii sp. nov.

Fig. 10, pl. 7, figs 9-12.

1971 ?Spiniferites sp. Wilson: 1265 ; pl. 4, figs 1-4. 1975 Spiniferites sp. A De Coninck: 332; fig. 3F, G,H.

Derivation of name. Named in honour of Jan De Coninck, Rijksuniversiteit Gent.

Diagnosis. The endocyst is subspherical. Dorsally the periphragm is closely appressed to the endophragm. On the ventral side a large pericoel separates the much expanded periphragm from the endophragm. The line of separation between endophragm and periphragm follows approximately the ambitus of the endocyst. In ambital view the pericyst is subcircular with the endocyst placed in a central position. The pericoel communicates with the exterior through a large hole in the mid-ventral part of the periphragm.

Wall layers are thin and smooth. Gonal and intergonal processes are present. The distal endings of processes are usually bi- or trifurcate. Where the pericoel is present underneath, the processes are reduced in length and often only the bi- or trifurcate endings are present.

Paratabulation is expressed as a precingular archaeopyle representing paraplate $3^{\prime \prime}$ and as parasutural lines and processes on the periphragm. The parasutural features are most distinct on the dorsal surface and clearly indicate the paraplates $4^{\prime}$ and $1^{\prime}, 2^{\prime \prime}-5^{\prime \prime}, 2 \mathrm{c}-5 \mathrm{c}(6 \mathrm{c}), 3^{\prime \prime \prime}-5^{\prime \prime \prime}\left(6^{\prime \prime \prime}\right), 1^{\prime \prime \prime \prime}$ and ps. The ventral hole in the periphragm intersects the paracingulum, which is otherwise continuous. The parasulcus therefore is partly included in the ventral hole in the periphragm.

Holotype. Fig. 10, C, D, pl. 7, figs 9, 10. MGUH 16152, England finder coordinates $\mathrm{T} 27 / 1$.

Dimensions: Endocyst length $=30 \mu \mathrm{m}$, breadth $=28 \mu \mathrm{m}$. Pericyst length $=50 \mu \mathrm{m}$, breadth $=52 \mu \mathrm{m}$.

Type locality and type stratum: Denmark, Svejstrup, Danian limestone, sample SV1. 

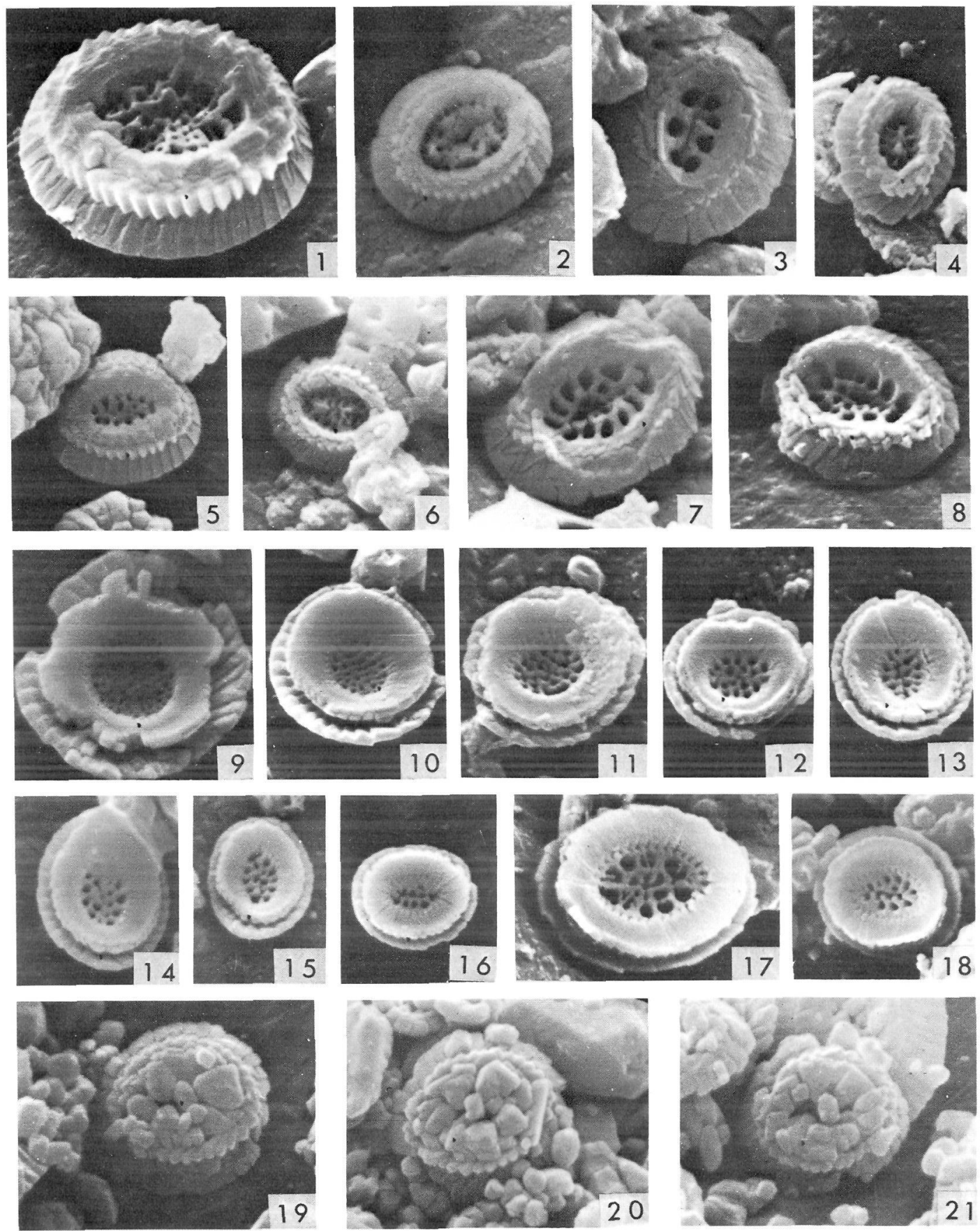

Plate 1.

Figs 1-18. Toweius pertusus. All illustrated specimens are from the Harre boring. Figs $1-6$ and $9-16$ are from the Danian, $0.4 \mathrm{~m}$ below the Danian-Selandian boundary. Figs 7,8 and 17, 18 are from the Selandian, $0.10 \mathrm{~cm}$ above the boundary. Figs $1-8$ are oblique distal views. Figs 9-18 are oblique proximal views.

Figs 19-21. Prinsius martinii, distal views. Harre boring, 12.6-13.1 m below the Danian-Selandian boundary.

All figures $6500 \times$. 

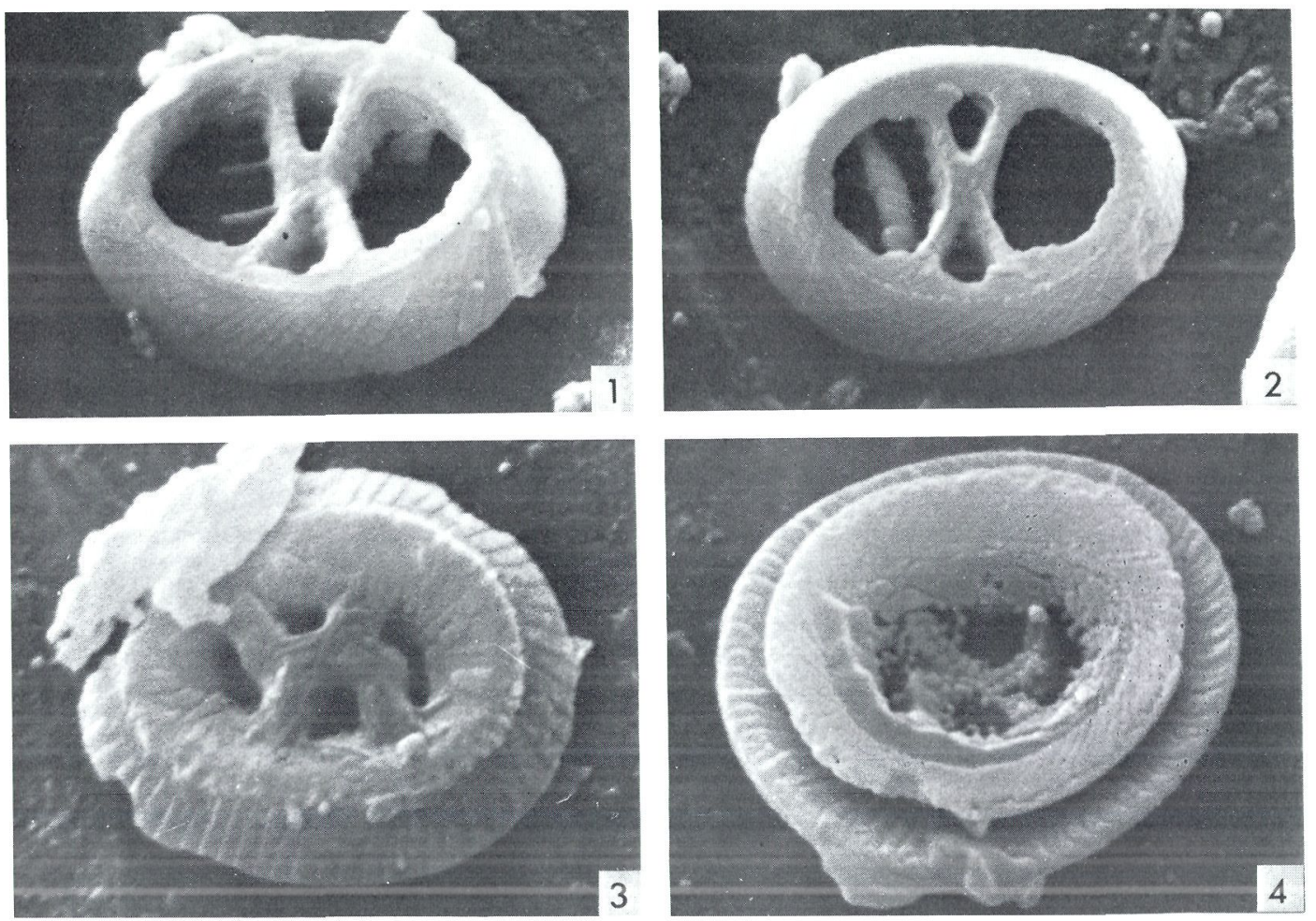

Plate 2.

Figs 1, 2. Neochiastozygus perfectus, oblique distal views. Harre boring, $0.4 \mathrm{~m}$ below the Danian-Selandian boundary. Figs 3,4 . Chiasmolithus bidens. Fig. 3. Oblique distal view. Fig. 4. Oblique proximal view. Harre boring, $0.4 \mathrm{~m}$ below the Danian-Selandian boundary.

All figures $6500 \times$.

Paratypes. Fig. 10A, B. MGUH 16153, coordinates L25/4. Fig. 10E, F, pl. 7, figs 11, 12. MGUH 16154, coordinates F25/4.

Discussion. Hystrichostrogylon coninckii sp. nov. differs from H. membraniphorum Agelopoulos 1964 and H. holohymenium Islam 1983, in the position of the pericoel and in the presence of a large hole in the periphragm in the parasulcal area.

Occurrence. Upper Maastrichtian, The Netherlands-Belgium (Wilson 1971). Danian and basal Selandian, Sweden (De Coninck 1975). Danian and Lower Selandian, Denmark. Bartonian, Belgium and Southern England (Jan De Coninck, pers. comm. 1984).

Genus Thalassiphora Eisenack \& Gocht 1960 emend. Gocht 1968

Thalassiphora inflata $\mathrm{sp}$. nov.

Fig. 11, pl. 7, figs 3-8.

Derivation of name. Latin, inflatus, with reference to the inflated appearance of the peripragm in most of the epicyst.

Diagnosis. The endocyst is ovoid. The periphragm is closely apressed to the endophragm except in the apical, ventral and lateral parts of the epicyst and on the ventral part of the post- cingular zone where wall layers are widely separated by a prominent pericoel. The pericoel communicates with the exterior through a large hole in the mid-ventral part of the periphragm. Wall layers are thin and smooth. Low indistinct processes may be present in the ventral part of the hypocyst. A few spines may be present along the paracingulum. A long spine-shaped protusion of the paracingular suture is present in the right margin of the ventral hole in the periphram.

Paratabulation is expressed as a precingular archaeopyle representing paraplate $3^{\prime \prime}$, and as parasutural lines or low ridges, indicating the paraplates $1^{\prime}-4^{\prime}$ and most of the paracingulum. Other faint lines on the expanded part of the periphragm may possibly represent parasutures, irregular features or folds in the flexible wall. The ventral hole in the periphragm intersects the paracingulum which is otherwise continuous. A parasulcus is therefore wholly or partly included in the ventral hole in the periphragm.

Holotype. Fig. 11C, D, pl. 7, figs 5, 6. MGUH 16155, England finder coordinates $\mathrm{W} 30 / 4$

Dimensions: Endocyst length $=32 \mu \mathrm{m}$, breadth $=30 \mu \mathrm{m}$. Pericyst length $=48 \mu \mathrm{m}$, breadth $=54 \mu \mathrm{m}$.

Type locality and type stratum: Denmark, Svejstrup, Kerteminde Marl, sample SV 8.

Paratypes. Fig. 11A, B, pl. 7, figs 3, 4. MGUH 16156, coordinates O 35/2. Pl. 7, figs 7, 8. MGUH 16157, coordinates R 40/ 3. 

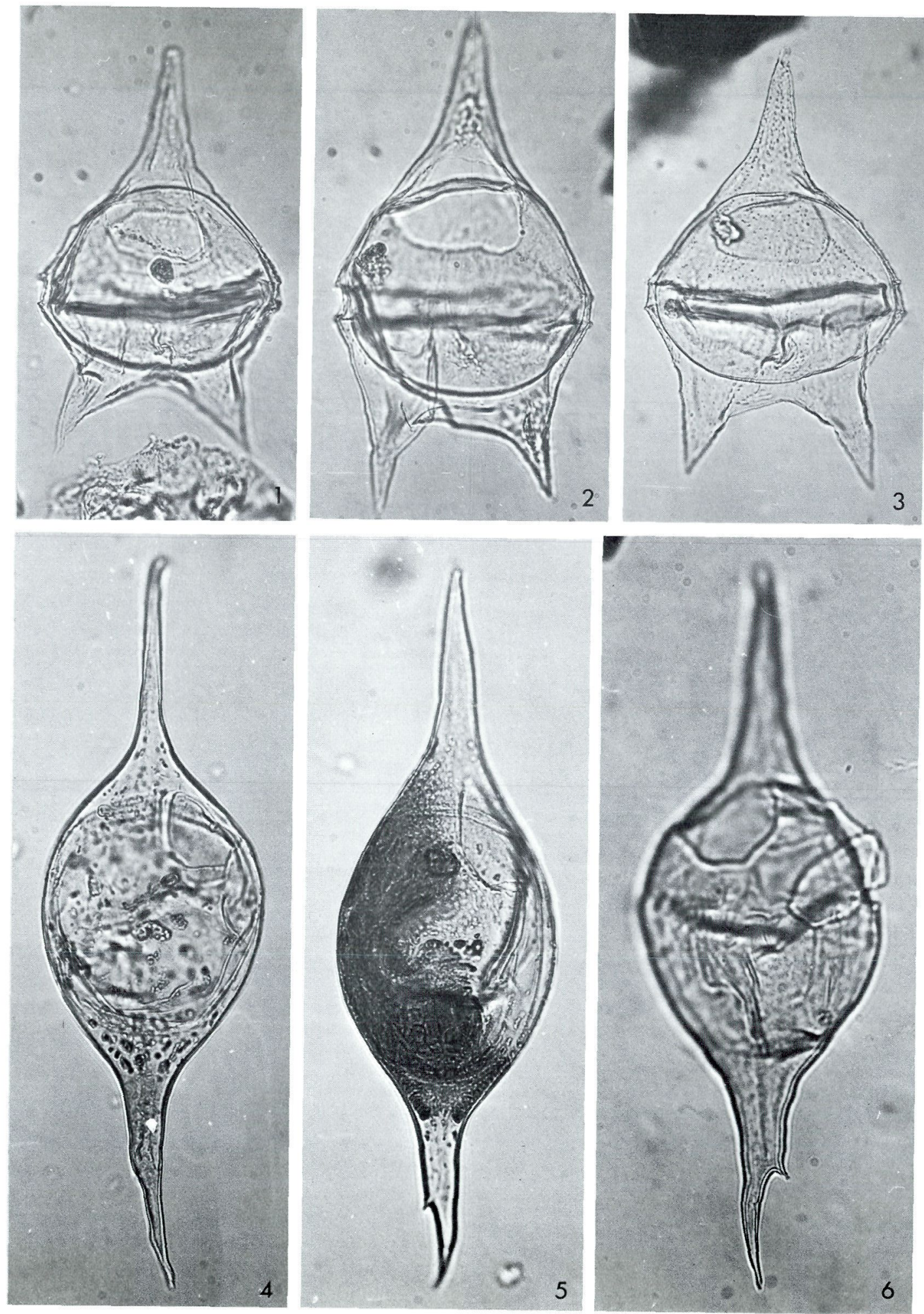

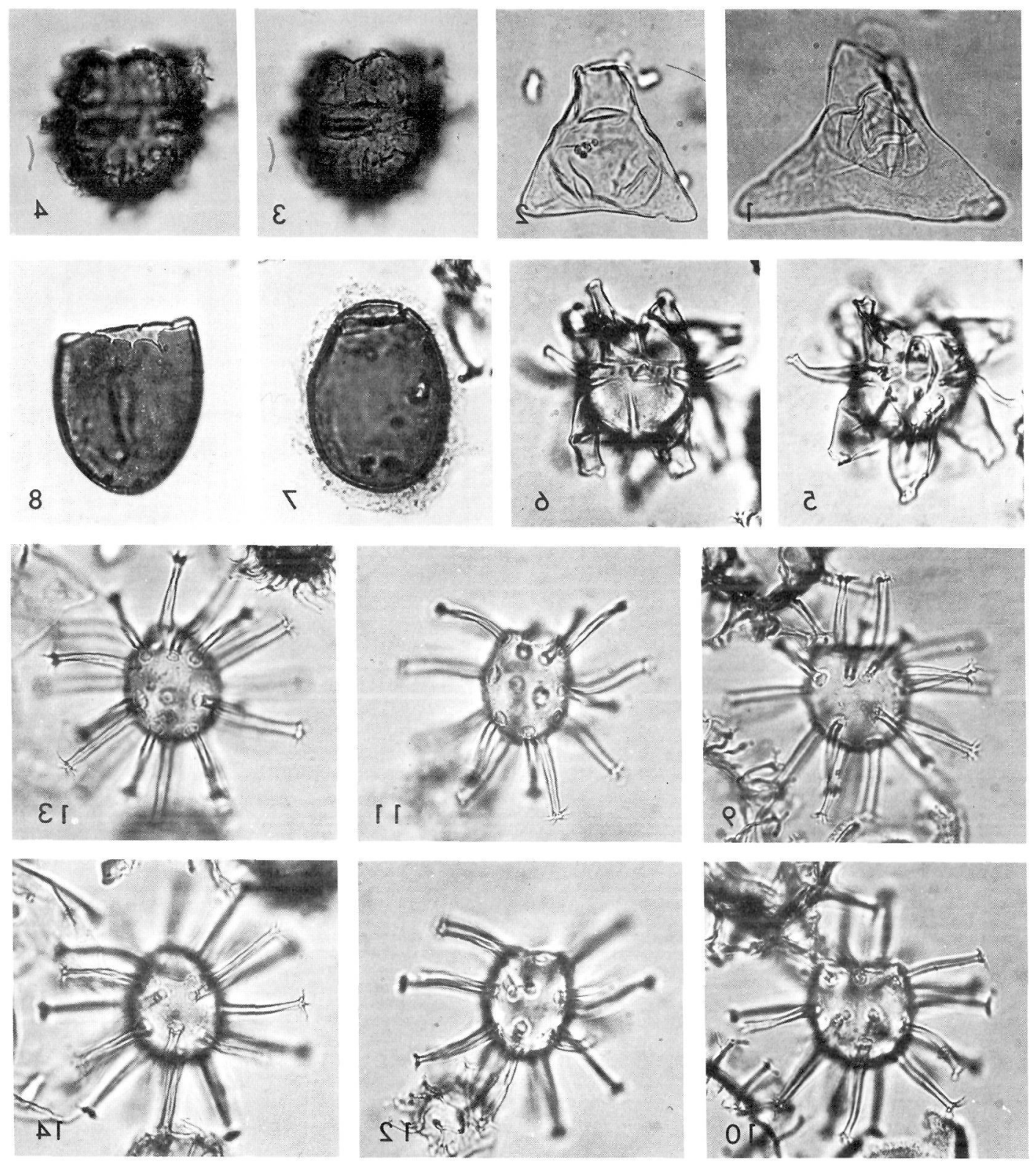

Plate 4.

Figs 1, 2. Trigonopyxidia ginella, Svejstrup, sample SV8.

Figs 3, 4. Alisocysta cf. margarita, specimen in different foci, Svejstrup, sample SV11.

Figs 5, 6. Hystrichokolpoma bulbosum, specimen in high focus (ventral side) and low focus (dorsal side), Svejstrup, sample SV1. Figs 7, 8. Caligodinum amiculum, Svejstrup, sample SV11.

Figs 9, 10. Hystrichosphaeridium? palmatum, specimen in high and low focus, Svejstrup, sample SV1.

Figs 11, 12. Hysterichospaeridium? palmatum, specimen in high and low focus, Svejstrup, sample SV1.

Figs 13, 14. Hystrichosphaeridium? palmatum, specimen in high and low focus, Svejstrup, sample SV2.

All figures $500 \times$.

Plate 3 .

Figs 1-3. Ceratiopsis speciosa, Svejstrup, sample SV9. Figs 4-6. Palaeocystodinium australinum, Svejstrup, samples SV9, SV9 and SV11, respectively.

All figures $500 \times$. 

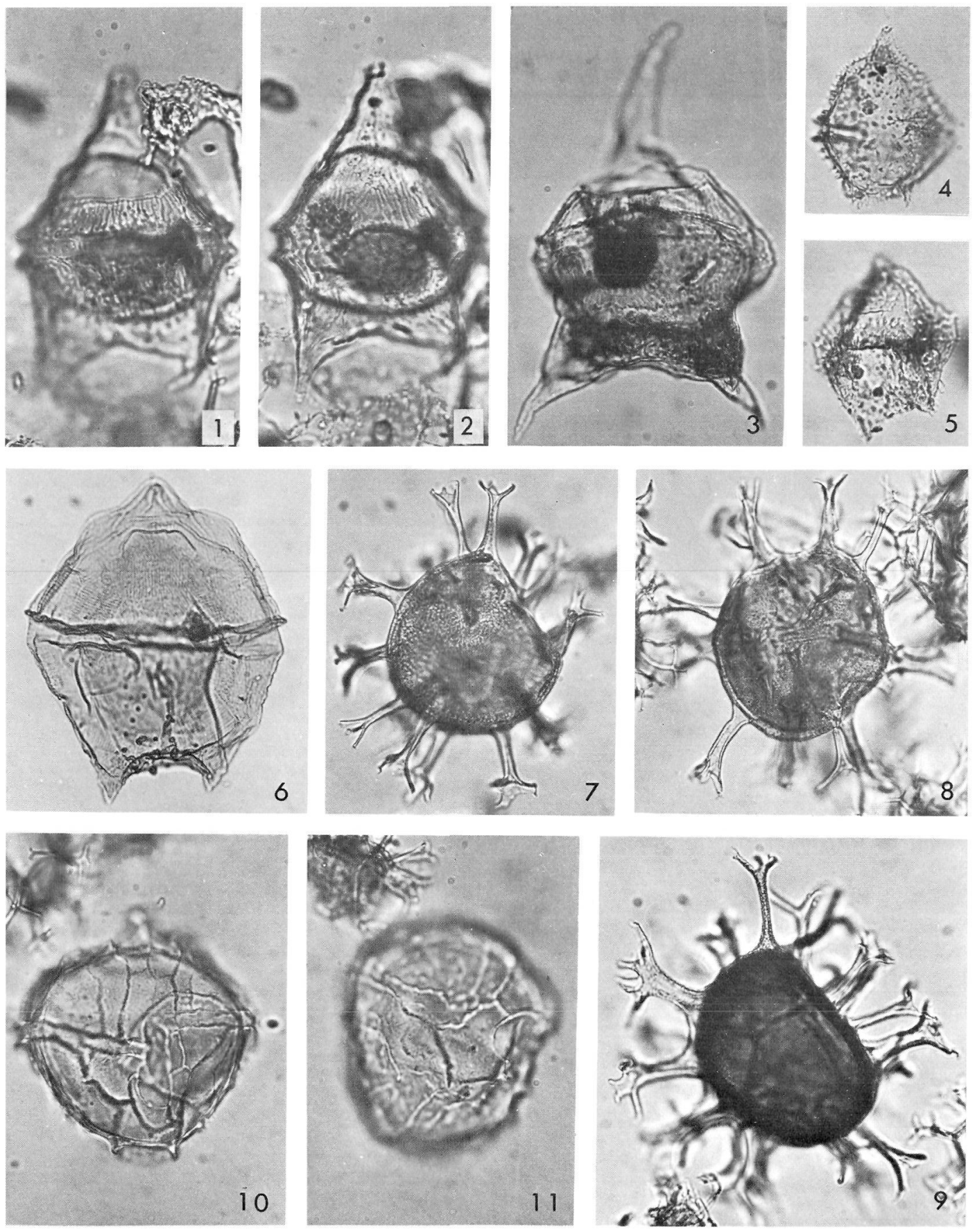

Plate 5.

Figs 1,2. Ceratiopsis striata, specimen in high (dorsal) and low (ventral) focus, Hvalløse boring, 10,4 m below the Danian-Selandian boundary.

Fig. 3. Ceratiopsis striata, Svejstrup, sample SV2.

Figs 4, 5. Spinidinium densispinatum, Svejstrup, sample SV3.

Fig. 6. Palaeoperidinium pyrophorum, Svejstrup, sample SV8.

Figs 7-9. Hafniasphaera graciosa, Svejstrup, sample SV1.

Fig. 10. Gonyaulacysta wetzelii, specimen in ventral view, Svejstrup, sample SV1.

Fig. 11. Gonyaulacysta wetzelii, specimen in antapical view, Svejstrup, sample SV1.

All figures $500 \times$. 

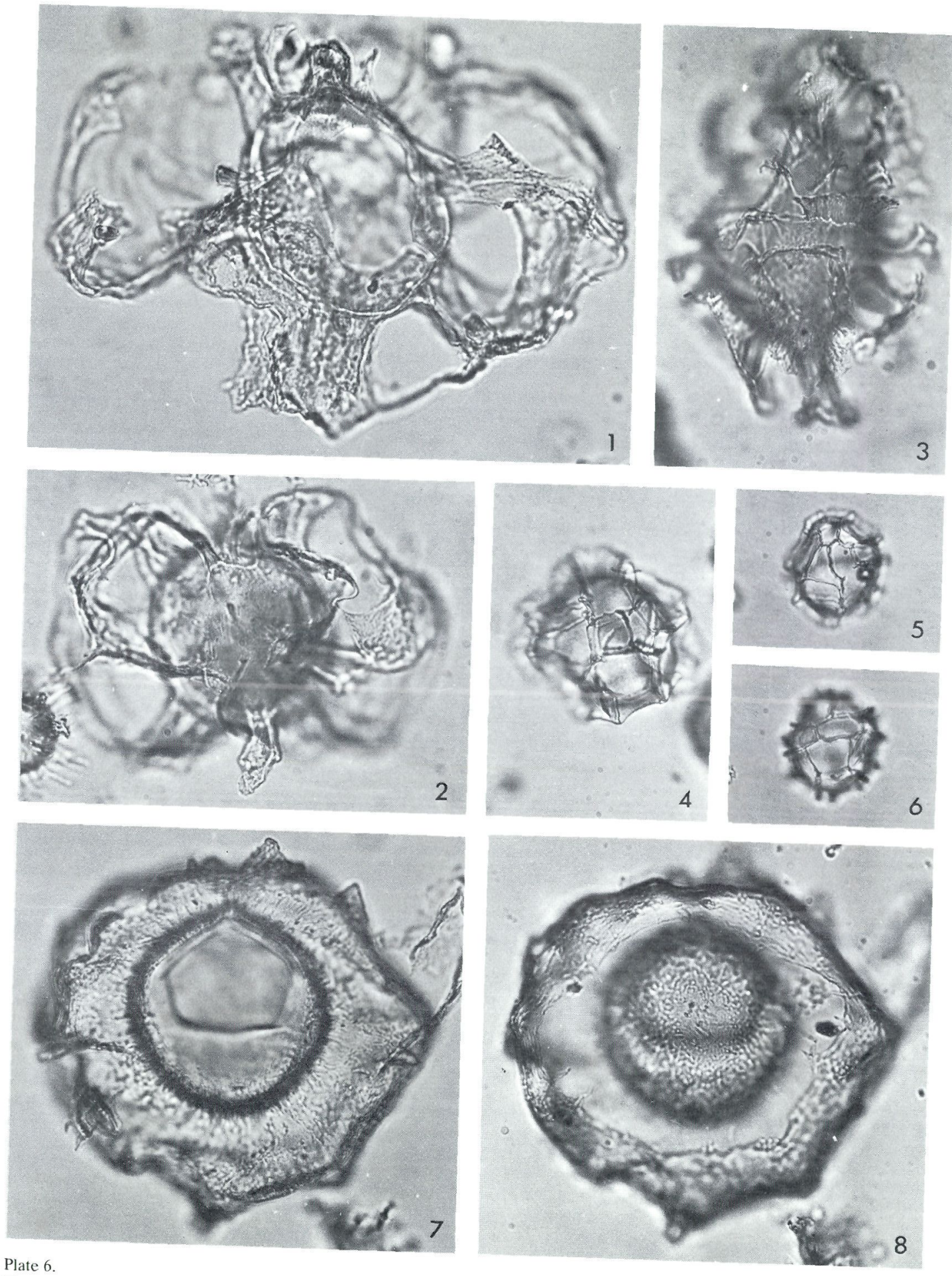

Plate 6.

Fig. 1.

Fig. 2. Cyclapophysis mon svejstrup, sample

Fig. 3. Danea californica, Svejstrup, Note isolated antapical process. Svejstrup, sample SV1.

Fig 4. Impanidinforica, Svejstrup, sample SV1.

Figs 5, 6. Impagidinium 1, high (posteroventral) focus, Svejstrup, sample SV11.

paracingulum. Svejstrup, sample SV8. Figs 7, 8 Thalassiphora

strup, sample SV1.

All figures $500 x$. 

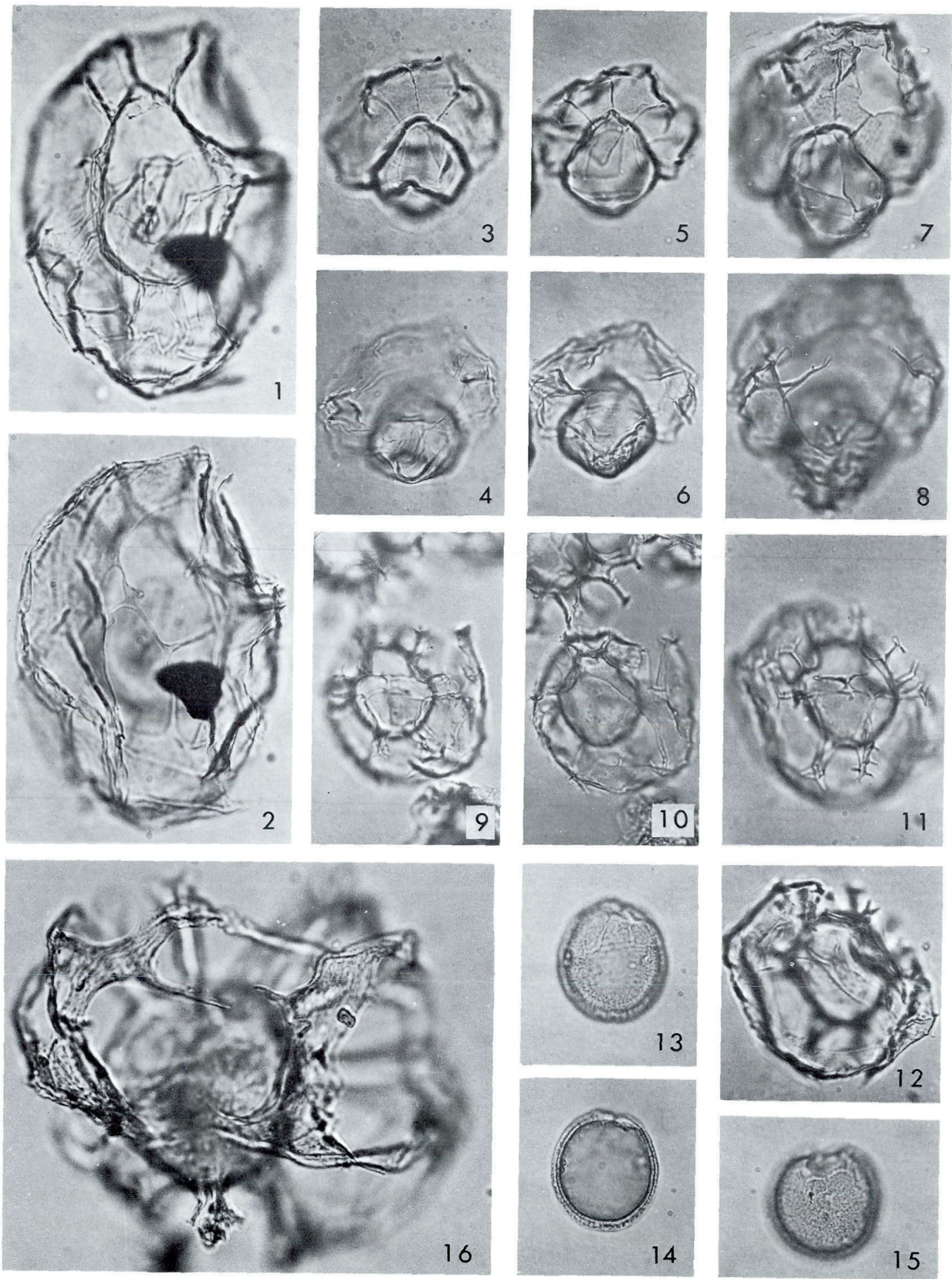
Discussion. Thalassiphora inflata $\mathrm{sp}$. nov. resembles $T$. delicata Williams \& Downie. It is distinguished on the absence of pericoel in the antapical area and furthermore by a different position of the ventral hole in the periphragm. In $T$. delicata the bole represents paraplate $1^{\prime \prime}$ according to Eaton (1976) and Manum (1979). T. inflata shows affinities also to the genus $\mathbf{L o}$ phocysta Manum, since the percoel in Lophocysta is only developed over a limited part of the endocyst. T. inflata differs, however, in the presence of a large hole in the periphragm in the parasulcal area.

Occurrence. Danian and Lower Selandian, Denmark.

\section{Type depository}

The type material is lodged in the type collection of the Geological Museum, $\emptyset$ ster Voldgade 5-7, DK-1350, Copenhagen, Denmark.

\section{References}

Agelopoulos, J. 1964: Hystrichostrogylon membraniphorum n.g.n.sp. aus dem Heiligenhafener Kieselton (Eozän). $N$. Jb. Geol. Paläont. Mh. 1964, 673-675.

Chandra, D. 1982: Oxidized coals. In: Stach, E., Mackowsky, M.-Th., et al.: Stach's textbook of Coal Petrology 3rd ed. Gebrüder Borntraeger, Berlin, 198-206.

De Coninck, J. 1975: Organic-walled microfossils from the Upper Danian and Middle Paleocene of Southern Sweden. Geol. Fören. Stockh. Förh. 97, 326-337.

Dinesen, A., Michelsen, O. \& Lieberkind, K. 1977: A survey of the Paleocene and Eocene deposits of Jylland and Fyn. Danmarks geol. Unders. Ser. B,2,15 pp.

Eaton, G. L. 1976: Dinoflagellate cysts from the Bracklesham Beds (Eocene) of the Isle of Wight, Southern England. Bull. Br. Mus. nat. Hist. (Geol) 26, 225-332.

Eisenack, A. \& Gocht, H. 1960: Neue Namen für einige Hystrichosphären der Bernsteinformation Ostpreussens. $N$. Jb. Geol. Paläont. Mh. 1960, 511-518.

Flagler, C. W. 1940: Report on the stratigraphy and foraminifera of the Viborg core drill profile, Mid-Jutland, Denmark. Danish American Prospecting Company (unpublished report) $37 \mathrm{pp}$.

Gocht, H. 1968: Zur Morphologie unde Ontogenie von Thalassiphora (Dinoflagellata). Palaeontographica A 129, 149156.

Gry, H. 1935: Petrology of the Paleocene sedimentary rocks of Denmark. Denmarks geol. Unders. (2), 61, 172 pp.
Hansen, J. M. 1977: Dinoflagellate stratigraphy and echinoid distribution in Upper Maastrichtian and Danian deposits from Denmark. Bull. geol. Soc. Denmark 26, 1-26.

Hansen, J. M. 1979a: A new dinoflagellate zone at the Maastrichtian/Danian boundary in Denmark. Danmarks geol. Unders. Arbog 1978, 131-140.

Hansen, J. M. 1979b: Dinoflagellate zonation around the boundary: In Birkelund, T. \& Bromley, R. G. (eds.): Cretaceous-Tertiary boundary events 1 . The Maastrichtian and Danian of Denmark, Copenhagen, 136-141.

Hansen, J. M. 1980: Stratigraphy and structure of the Paleocene in central West Greenland and Denmark. Ph.D. thesis, Copenhagen University. $155 \mathrm{pp}, 94$ figs. (unpublished).

Hansen, H. J. 1968: On the biostratigraphical age of the lower Selandian of Denmark. Meddr. dansk geol. Foren. 18, 277-284.

Hansen, H. J. 1970: Danian foraminifera from Nugssuaq, West Greenland. Gronlands Geol. Unders. 93, $132 \mathrm{pp}$.

Hardenbol, J. \& Berggren, W. A. 1978: A new Paleogene numerical time scale. A. A. P. G. Studies in Geology 6, 213234.

Iokim, C. 1979: Etude comparative des dinoflagellés du Tertiaire Inférieur de la Mer du Labrador et de la Mer du Nord. Ph. D. thesis. Université Pierre et Marie Curie, Paris. 204 pp. (unpublished).

Islam, M. A. 1983: Dinoflagellate cysts from the Eocene cliff sections of the Isle of Sheppey, Southeast England. Revue Micropaléont. 25, 231-250.

Kjcllström, G. \& Hansen, J. M. 1981: Dinoflagellate biostratigraphy of the Cretaceous-Tertiary boundary in southern Scandinavia. Geol. Fören. Stockh. Förh. 103, 271-278.

Knox, R. W. O'B., Morton, A. C. \& Harland, R. 1981: Stratigraphical Relationships of Palaeocene Sands in the UK Sector of the Central North Sea. In: Illing, L. V. \& Hobson, G. D. (eds.): Petroleum Geology of the Continental Shelf of North-West Europe. Institute of Petroleum, London, 267-281.

Manum, S. B. 1979: Two new Tertiary dinocyst genera from the Norwegian Sea: Lophocysta and Evittosphaerula. Rev. Palaeobot. Palynol. 28, 237-248.

Martini, E. 1971: Standard Tertiary and Quaternary calcareous nannoplankton Zonation. Proc. II Plankt. Conf. Roma, 739-785.

Morgenroth, P. 1968: Zur Kenntniss der Dinoflagellaten und Hystrichosphacridien des Danian. Geol. Jb. 86, 533-578.

Okada, H. \& Thierstein, H. R. 1979: Calcareous nannoplankton - Leg 43, Deep Sea Drilling Project. In Tucholke, B. E., Vogt, P. R., et al (eds.): Initial Reports of the Deep Sea Drilling Project. Washington, 43, 507-573.

Perch-Nielsen, K. 1969a: Die Coccolithen einiger Dänischer Maastrichtien- und Danienlocalitäten. Meddr. dansk geol. Foren. 19, 51-68.

Plate 7.

Figs 1,2. Thalassiphora delicata. Specimen in low (dorsal) and high (ventral) view. The ventral hole in the periphragm is crossed by thin trabeculae of periphragm. Svejstrup, sample SV9.

Figs 3, 4. Thalassiphora inflata sp. nov. Paratype MGUH 16156. Low (dorsal) and high (ventral) focus. Svejstrup, sample SV8.

Figs 5, 6. Thalassiphora inflata sp. nov. Holotype. Low (dorsal) and high (ventral) focus. Svejstrup, sample SV8.

Figs 7, 8. Thalassiphora inflata sp. nov. Paratype MGUH 16157. Low (dorsal) and high (ventral) focus. Viborg 1, Danian limestone, sample 227.

Figs 9, 10. Hystrichostrogylon coninckii sp. nov. Holotype. Low (dorsal) and high (ventral) focus. Svejstrup, sample SV1.

Figs 11, 12. Hystrichostrogylon coninckii sp. nov. Paratype MGUH 16154. High (dorsal) and low (ventral) focus. Svejstrup, sample SV1.

Figs 13, 14. Membranosphaera sp. A De Con. 1975. Specimen in high and sectional focus. Svejstrup, sample SV2.

Fig. 15. Membranosphaera sp. A De Con. 1975. Svejstrup, sample SV2.

Fig. 16. Cyclapophysis monmouthensis. High focus showing distal interconnections between precingular and postcingular processes. Note isolated antapical process. Svejstrup, sample SV2.

All figures $500 \times$. 
Perch-Nielsen, K. 1969b: Elektronenmikroskopische Untersuchungen der Coccolithophoriden der Dan-Scholle von $\mathrm{Ka}$ tharinenhof (Fehmarn) N. Jb. Geol. Paläont. Abh. 133, 317-332.

Perch-Nielsen, K. 1971a: Einige neue Coccolithen aus dem Paleozän der Bucht von Biskaya. Bull. geol. Soc. Denmark, $20,347-361$.

Perch-Nielsen, K. 1971b: Neue Coccolithen aus dem Paleozän von Dänemark, der Bucht von Biskaye und Eozän der Labrador Sea. Bull. geol. Soc. Denmark 21, 51-66.

Perch-Nielsen, K. 1977: Albian to Pleistocene calcareous Nannofossils form the western South Atlantic, D. S. D. P. Leg 39. In: Supko, P. R., Perch-Nielsen, K., et al (eds.): Initital Reports of the Deep Sea Drilling Project, Washington, 39, 699-823.

Perch-Nielsen, K. 1979a: Calcareous nannofossil zonation at the Cretaceous/Tertiary boundary in Denmark. In: Birkelund, T. \& Bromley, R. G. (eds.): Cretaceous-Tertiary boundary events $I$. The Maastrichtian and Danian of Denmark, Copenhagen, 115-135.
Perch-Nielsen, K. 1979b: Calcareous nannofossils in Cretaceous/Tertiary boundary sections in Denmark. In: Christensen, W. K. \& Birkelund, T. (eds.): Cretaceous-Tertiary boundary events II. Proceedings, 120-127.

Perch-Nielsen, K. \& Hansen, J. M. 1981: Selandian. In: Pomerol, C. (ed.): Stratotypes of Paleogene Stages. Mem. hors. série (2) du Bull. d'inf. geol. bassin de Paris, 219-230.

Romein, A. J. T. 1979: Lineages in early Paleogene calcareous nannoplankton. Utrecht Micropal. Bull. (22) $231 \mathrm{pp.}$

Stover, L. E. \& Evitt, W. R. 1978: Analyses of Pre-Pleistocene organic-walled dinoflagellates. Stanford University publications. Geological Sciences $15,300 \mathrm{pp}$.

Thomsen, E. 1981: Revised definition of the Danian. In: Pomerol, C. (ed.): Stratotypes of Paleogene Stages. Mem. hors série (2) du Bull. d'inf. geol. bassin de Paris, 81-99.

Wilson, G. J. 1971: Observations on European Late Cretaceous dinoflagellate cysts. In: Farinacci, A. (ed.): Proc. II Plankt. Conf. Roma 1970. Roma, 1259-1275.

$\emptyset$ dum, H. 1926: Studier over Daniet i Jylland og på Fyn. Danmarks geol. Unders. (2) 45, 306 pp. 